\title{
Phytoplankton photosynthetic parameters off Baja California: A tool to estimate primary production with remote sensing data
}

\section{Parámetros fotosintéticos frente a Baja California: Una herramienta para estimar la producción primaria con datos de sensores remotos}

\author{
Ramón Sosa-Ávalos ${ }^{1 *}$, Reginaldo Durazo ${ }^{2}$, B Greg Mitchell², Jushiro Cepeda-Morales ${ }^{4}$, Gilberto \\ Gaxiola-Castro $^{5 \dagger}$ \\ ${ }^{1}$ Centro Universitario de Investigaciones Oceanológicas, Universidad de Colima, Carretera Manzanillo-Barra \\ de Navidad, km 20, Manzanillo, CP 28860, Colima, México. \\ 2 Universidad Autónoma de Baja California, Facultad de Ciencias Marinas, Carretera Ensenada-Tijuana No. \\ 3917, Fraccionamiento Playitas, Ensenada, CP 22860, Baja California, México. \\ ${ }^{3}$ Integrative Oceanography Division, Scripps Institution of Oceanography, University California San Diego, \\ 9500 Gilman Drive No. 0218, La Jolla, CA 92093, USA. \\ ${ }^{4}$ Laboratorio de Percepción Remota Satelital de Ecosistemas Costeros y Oceánicos, CENIT2, Universidad \\ Autónoma de Nayarit. Ciudad de la Cultura, Amado Nervo s/n, Tepic, CP 63155, Nayarit, México. \\ ${ }^{5}$ Departamento de Oceanografía Biológica, División de Oceanología, Centro de Investigación Científica y \\ Educación Superior de Ensenada (CICESE). Carretera Ensenada-Tijuana No. 3918, Zona Playitas, Ensenada, \\ CP 22860, Baja California, México. \\ * Corresponding author. E-mail: rsosa@ucol.mx
}

\begin{abstract}
Phytoplankton photosynthetic parameters (maximum light utilization coefficient, $\alpha^{*}$; maximum photosynthetic rate, $P_{m}^{*}$; maximum quantum yield, $\phi_{\max }$ ) off Baja California were estimated from samples collected at the $50 \%$ light level during winter, spring, summer, and autumn 1999. Chlorophyll concentration was also determined, and in situ experiments were conducted using the ${ }^{14} \mathrm{C}$ method to determine primary production (PP) in the euphotic zone. The highest $\alpha^{*}$ and $\phi_{\max }$ values were found during the spring survey, mainly at the coastal areas, associated with diatom and dinoflagellate abundances and high chlorophyll concentrations. However, high $P_{m}^{*}$ values were measured during autumn in both inshore and offshore areas due to the presence of smaller phytoplankton cells. The average profiles of the photosynthetic parameters $\left(\alpha_{(z)}^{*}\right.$ and $\left.P_{m(z)}^{*}\right)$ in the water column were estimated for 2 regions. These parameters were used to estimate PP with semi-analytical models. Modeled PP was contrasted with in situ PP to validate our calculated photosynthetic parameters in the euphotic zone. In general, modeled PP values were similar to in situ values $\left(94 \mathrm{mg} \mathrm{C} \cdot \mathrm{m}^{-2} \cdot \mathrm{h}^{-1}\right)$, with a high correlation coefficient $(r=0.85)$. Modeled PP for coastal waters in the northern and central regions was 1.5 -fold greater than in situ estimates during spring. In conclusion, when used with remotely sensed phytoplankton pigment and surface irradiance data, the average profiles of $\alpha_{(z)}^{*}$ and $P_{m(z)}^{*}$ could be a useful tool to calculate PP in our study area.
\end{abstract}

Key words: photosynthetic parameters, modeled primary production, chlorophyll $a$, remote sensing, Baja California.

RESUMEN. Los parámetros fotosintéticos (coeficiente de máxima utilización de la luz, $\alpha^{*}$; tasa fotosintética máxima, $P_{m}^{*}$; eficiencia cuántica máxima, $\phi_{\max }$ ) fueron estimados para la región frente a Baja California a partir de muestras recolectadas del $50 \%$ de irradiancia superficial durante invierno, primavera, verano y otoño de 1999. Además, se determinó la concentración de clorofila y se realizaron experimentos in situ para determinar la producción primaria (PP) en la zona eufótica con el método ${ }^{14} \mathrm{C}$. Los valores más altos de $\alpha^{*} \mathrm{y} \phi_{\max }$ se registraron durante la primavera, principalmente en la zona costera, y estuvieron relacionados con la abundancia de diatomeas y dinoflagelados y con las altas concentraciones de clorofila. Sin embargo, los valores altos de $P_{m}^{*}$ se midieron durante el otoño en la zona costera y la zona oceánica debido a la presencia de fitoplancton de menor tamaño. Los perfiles promedio de los parámetros fotosintéticos $\left(\alpha_{(z)}^{*}\right.$ y $\left.P_{m(z)}^{*}\right)$ fueron estimados para la columna de agua en 2 regiones (norte y central). A partir de estos datos, se estimó la PP de ambas regiones oceanográficas usando modelos semi-analíticos. Para validar los parámetros fotosintéticos calculados para la zona eufótica, la PP modelada se comparó con la PP in situ. En general, la PP modelada fue similar a los valores in situ $\left(94 \mathrm{mg} \mathrm{C} \cdot \mathrm{m}^{-2} \cdot \mathrm{h}^{-1}\right)$, con un alto coeficiente de correlación $(r=0.85)$. Se encontró que la PP modelada para aguas costeras de las regiones norte y central fue 1.5 veces mayor que la estimada in situ durante la primavera. Los resultados sugieren que, junto con información sobre pigmentos de fitoplancton y datos de irradiancia superficial medidos por sensores remotos, los perfiles promedio de $\alpha_{(z)}^{*}$ y $P_{m(z)}^{*}$ pueden ser una herramienta útil para calcular la PP en nuestra área de estudio.

Palabras clave: parámetros fotosintéticos, producción primaria modelada, clorofila $a$, sensores remotos, Baja California. 


\section{INTRODUCTION}

Primary production (PP) determination based on data derived from remote sensors, requires regional and temporal estimations of phytoplankton photosynthetic parameters such as maximum light utilization coefficient $\left(\alpha^{*}\right)$ and maximum photosynthetic rate $\left(P_{m}^{*}\right)$ (Platt and Sathyendranath 1988, Platt et al. 1991, Sathyendranath et al. 1996). It is also necessary to consider the spectral dependence of photosynthetically active radiation (PAR, 400-700 nm) in the water column and the spatial and vertical variability of the chlorophyll-specific absorption coefficient $\left(a_{\phi}^{*}\right)$ (Behrenfeld and Falkowski 1997) to estimate PP for a particular region.

Spatial and temporal variabilitites in phytoplankton photophysiology are an important source of uncertainty in the models used to estimate PP (Sosik 1996). However, not all parameters required by the models for PP estimation with remote sensing data are available for every pixel (Platt and Sathyendranath 1988). One of the main issues with PP estimation based on remote sensing data is the extrapolation of local determinations of spatial and temporal photosynthetic parameters and bio-optical properties to large regions and long periods of time. This constitutes one of the most important tasks in biological oceanography (Longhurst et al. 1995, Sathyendranath et al. 1995). One way to solve this issue is to divide the ocean into regions with similar oceanographic characteristics (Longhurst et al. 1995, Sathyendranath et al. 1995), where photosynthetic parameters derived from the photosynthesis-irradiance (P-E) curves remain almost constant accross a region, over a season, or in time.

Satellite ocean color sensors have increased the use of synoptic images of phytoplankton biomass to perform global estimates of oceanic carbon fixation through phytoplankton photosynthesis (Platt and Sathyendranath 1988, Behrenfeld and Falkowski 1997). Thus, remote sensors are a useful tool for ocean monitoring at large scales, since they also allow for synoptic coverage and the possibility of obtaining nearly real-time data (Sathyendranath and Platt 1989).

If chlorophyll concentrations and surface irradiance $\left(E_{P A R}\right)$ are determined from remote sensing data, average $\alpha^{*}$ and $P_{m}^{*}$ data can be used to make regional-scale estimates of PP with semi-analytical models that take different variability time scales into account. For example, in the southern region of the California Current the average values for $\alpha^{*}$ and maximum quantum yield of photosynthesis $\left(\phi_{\max }\right)$ are expected to be greater during spring due to the abundance of larger phytoplankton such as diatoms and dinoflagellates and to the high light absorption coefficient of phytoplankton. In contrast, during summer and autumn, average $P_{m}^{*}$ values will be much higher due to the dominance of small phytoplankton cells that grow at high irradiances. Assuming that average $\alpha^{*}$ and $P_{m}^{*}$ values adequately represent the response of phytoplankton to environmental changes in the area, PP estimates based on semi-analytical models could be comparable to the in situ PP.

\section{INTRODUCCIÓN}

La determinación de la producción primaria (PP) a partir de datos derivados de sensores remotos requiere de la estimación regional y temporal de los parámetros fotosintéticos del fitoplancton, como el coeficiente de máxima utilización de la luz $\left(\alpha^{*}\right)$ y la tasa fotosintética máxima $\left(P_{m}^{*}\right)$ (Platt y Sathyendranath 1988, Platt et al. 1991, Sathyendranath et al. 1996). También es necesario considerar la dependencia espectral de la radiación fotosintéticamente activa (PAR, por sus siglas en inglés; 400-700 nm) en la columna de agua y la variabilidad espacial y vertical del coeficiente específico de absorción por el fitoplancton $\left(a_{\phi}^{*}\right)$ (Behrenfeld y Falkowski 1997) para estimar la PP en una determinada región.

La variabilidad espacial y temporal de la fotofisiología del fitoplancton es una importante fuente de incertidumbre en los modelos utilizados para estimar la PP (Sosik 1996). No todos los parámetros requeridos por los modelos utilizados para estimar la PP a partir de datos de sensores remotos se encuentran disponibles en cada píxel (Platt y Sathyendranath 1988). Uno de los principales problemas en la estimación de PP a partir de datos de sensores remotos es la extrapolación espacial y temporal de las determinaciones locales de los parámetros fotosintéticos y propiedades bio-ópticas a grandes regiones y extensos periodos de tiempo. Esto constituye una de las tareas más importantes en oceanografía biológica (Longhurst et al. 1995, Sathyendranath et al. 1995). Una manera de resolver este problema es dividir el océano en regiones con características oceanográficas similares (Longhurst et al. 1995, Sathyendranath et al. 1995), donde los parámetros fotosintéticos derivados de las curvas de fotosíntesis-irradiancia (P-E) permanecen casi constantes para una región, para una estación o en el tiempo.

Los satélites con sensores remotos de color del océano han incrementado el uso de imágenes sinópticas de la biomasa de fitoplancton para realizar estimaciones globales de la fijación de carbono oceánico a través de la fotosíntesis del fitoplancton (Platt y Sathyendranath 1988, Behrenfeld y Falkowski 1997). Así, los sensores remotos son una herramienta útil para el monitoreo a gran escala del océano, ya que, además, proveen una cobertura sinóptica y la posibilidad de tener datos casi en tiempo real (Sathyendranath y Platt 1989).

Si se conocen las concentraciones de clorofila y la irradiancia superficial $\left(E_{P A R}\right)$ a partir de la información de sensores remotos, es posible utilizar datos promedio de $\alpha^{*}$ y $P_{m}^{*}$ para estimar la PP en una escala regional usando modelos semianalíticos que tomen en cuenta diferentes escalas de variabilidad temporal. Por ejemplo, en la región sur de la corriente de California se espera que los valores promedio de $\alpha^{*}$ y de la eficiencia cuántica máxima de la fotosíntesis $\left(\phi_{\max }\right)$ sean mayores durante la primavera debido a la abundancia de fitoplancton más grande como diatomeas y dinoflagelados, y a los altos coeficientes de absorción de luz por el fitoplancton. En contraste, durante verano y otoño, los valores 
In the present study phytoplankton photophysiology is studied by determining average photosynthetic parameter values and bio-optical properties in the southern region of the California Current, off Baja California (Mexico). This region is considered a transition zone due to the influence of cooler, less-saline subarctic waters and warmer, saltier water of tropical and subtropical origin (Durazo and Baumgartner 2002, Durazo 2009). The seasonal variability of parameters is studied and the possibility for these parameter to be extrapolated to a regional scale is evaluated. Together with remote sensing data, PP is estimated to represent the oceanographic conditions of this transitional region.

\section{MATERIALS AND METHODS}

Oceanographic cruises were conducted in the southern region of the California Current, off Baja California, during each season in 1999 (Fig. 1). Water samples were collected by the cruises at the depths corresponding to $100 \%, 50 \%$, $30 \%, 20 \%, 10 \%$, and $1 \% E_{P A R}$ in hydrographic stations occupied near local midday. Also, vertical profiles of spectral irradiance $\left(E_{d}[\lambda], \mu \mathrm{W} \cdot \mathrm{cm}^{-2} \cdot \mathrm{nm}^{-1}\right)$ and PAR $(400-700 \mathrm{~nm}$, $\mu$ mol photons $\left.\cdot \mathrm{m}^{-2} \cdot \mathrm{s}^{-1}\right)$ were measured using a PRR-600 radiometer (Biospherical Instruments) which was lowered into the water over the stern of the ship.

For chlorophyll (Chla) determination $2 \mathrm{~L}$ of seawater were collected at each depth; water was then passed through Whatman GF/F filters, which were frozen in liquid nitrogen. In the laboratory, phytoplankton Chla was extracted with $90 \%$ acetone at $4{ }^{\circ} \mathrm{C}$ and in complete darkness for $24 \mathrm{~h}$ according to the recommendations by Venrick and Hayward (1984). Chlorophyll concentration $\left(\mathrm{mg} \cdot \mathrm{m}^{-3}\right)$ was determined by the fluorometric method (Yentsch and Menzel 1963, Holm-Hansen et al. 1965) using a Turner Designs A10 fluorometer calibrated with pure Chla (Sigma).

In addition, $2 \mathrm{~L}$ of water were collected at each depth to determine the light absorption coefficient of particles $\left(a_{p}[\lambda]\right)$. Water was filtered through GF/F filter, which were immediately frozen in liquid nitrogen. Light absorption by the total amount of particles retained in the filters was measured using a Varian Cary 1E UV-Vis spectrophotometer, according to the method described by Kishino et al. (1985), Mitchell (1990), and Mitchell et al. (2003). The same procedure was followed to determine the light absorption coefficient of detritus $\left(a_{d}[\lambda]\right)$. The light absorption coefficient of phytoplankton $\left(a_{\phi}[\lambda]\right)$ was calculated as the difference between $a_{p}(\lambda)$ and $a_{d}(\lambda)$.

Water samples were also used for identifying and quantifying phytoplankton by fixation with $2 \mathrm{~mL}$ of Lugol solution neutralized with acetic acid. A $50-\mathrm{mL}$ aliquot was placed in settling chambers for $24 \mathrm{~h}$ and subsequently analyzed under an inverted microscope following the technique described by Utermöhl (1958). promedio de $P_{m}^{*}$ serán más altos debido a la dominancia de pequeñas células de fitoplancton que crecen a altas irradiancias. Si partimos de la premisa de que el promedio de $\alpha^{*}$ y $P_{m}^{*}$ representa adecuadamente la respuesta del fitoplancton a los cambios ambientales en el área, es factible que la PP estimada a partir de modelos semianalíticos sea comparable con la PP in situ.

En el presente trabajo se estudia la fotofisiología del fitoplancton a través de la determinación de valores promedio de los parámetros fotosintéticos y las propiedades bio-ópticas en la región sur de la corriente de California, frente a Baja California (México). Esta región se considera una zona de transición debido a la influencia de aguas subárticas de menor temperatura y salinidad, y aguas cálidas y de mayor salinidad de origen tropical y subtropical (Durazo y Baumgartner 2002, Durazo 2009). Se estudia la variabilidad estacional de los parámetros y se evalúa su potencial de ser extrapolados a una escala regional. En conjunto con la información de sensores remotos, se estima la PP representativa de las condiciones oceanográficas de esta región transicional.

\section{MATERIALES Y MÉTODOS}

Durante 1999 se realizaron cruceros oceanográficos en la región sur de la corriente de California, frente a Baja California, en cada estación del año (Fig. 1). En los cruceros se recolectaron muestras de agua de las profundidades que correspondieron al $100 \%, 50 \%, 30 \%, 20 \%, 10 \%$ y $1 \% E_{P A R}$ en estaciones hidrográficas cuya ocupación fue cercana al mediodía local. Además, se midieron perfiles verticales de irradiancia espectral $\left(E_{d}[\lambda], \mu \mathrm{W} \cdot \mathrm{cm}^{-2} \cdot \mathrm{nm}^{-1}\right)$ y PAR (400-700 nm, $\mu \mathrm{mol}$ fotones $\cdot \mathrm{m}^{-2} \cdot \mathrm{s}^{-1}$ ) con un radiómetro (PRR-600, Biospherical Instruments) que fue bajado al agua por la popa del barco.

Para el análisis de clorofila (Chla) se recolectaron $2 \mathrm{~L}$ de agua de mar a cada profundidad; el agua se pasó a través de filtros Whatman $\mathrm{GF} / \mathrm{F}$ y los filtros fueron congelados en nitrógeno líquido. En el laboratorio, la Chla del fitoplancton fue extraída con acetona al $90 \%$ a $4^{\circ} \mathrm{C}$ y en oscuridad por $24 \mathrm{~h}$ de acuerdo con las recomendaciones de Venrick y Hayward (1984). La concentración de Chla $\left(\mathrm{mg} \cdot \mathrm{m}^{-3}\right)$ se determinó con el método fluorométrico (Yentsch y Menzel 1963, Holm-Hansen et al. 1965) utilizando un fluorímetro Turner Designs A10 calibrado con Chla pura (Sigma).

Adicionalmente, se recolectaron $2 \mathrm{~L}$ de agua a cada profundidad para determinar el coeficiente de absorción de luz por partículas $\left(a_{p}[\lambda]\right)$. El agua fue filtrada por medio de filtros $\mathrm{GF} / \mathrm{F}$, que fueron inmediatamente congelados en nitrógeno líquido. La absorción de la luz por las partículas totales retenidas en los filtros fue medida en un espectrofotómetro Varian Cary 1E UV-Vis, de acuerdo con el método descrito por Kishino et al. (1985), Mitchell (1990) y Mitchell et al. (2003). Se siguió el mismo procedimiento para determinar el coeficiente de absorción de luz por detritos $\left(a_{d}[\lambda]\right)$. El 


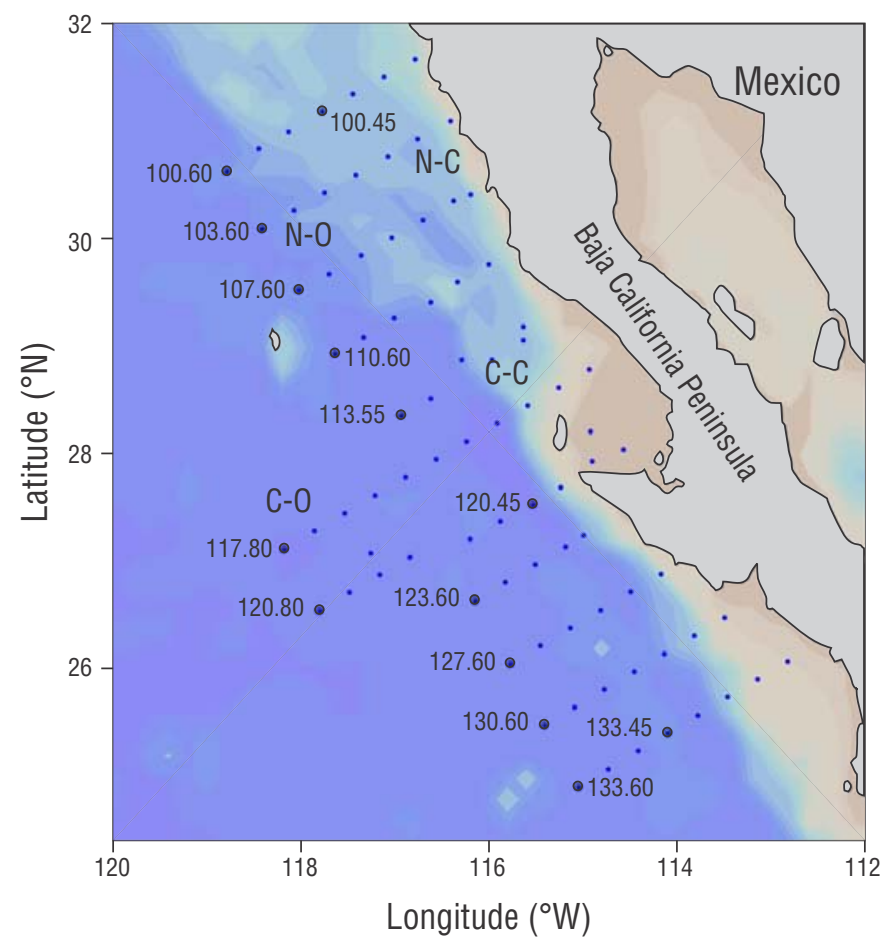

Figure 1. Location of the IMECOCAL (Spanish acronym for the Mexican Research of the California Current program) hydrographic lines and stations (filled circles). The northern region (lines 100-110) is subdivided into coastal $(\mathrm{N}-\mathrm{C}$, from shore to stations 000.45$)$ and oceanic $(\mathrm{N}-\mathrm{O}$, starting at stations 000.50$)$ zones, and the central region (líneas 113-133) is also subdivided into coastal and oceanic zones ( $\mathrm{C}-\mathrm{C}$ and $\mathrm{C}-\mathrm{O}$, respectively).

Figura 1. Ubicación de las líneas hidrográficas y estaciones (círculos rellenos) del programa Investigaciones Mexicanas de la Corriente de California (IMECOCAL). Se muestran la región norte (líneas 100-110) subdividida en zona costera (N-C, desde la costa hasta la estación 000.45$)$ y zona oceánica $(\mathrm{N}-\mathrm{O}$, a partir de la estación 000.50) y la región central (líneas 113-133) también subdividida en zona costera y zona oceánica (C-C y C-O, respectivamente).

In total 35 experiments were conducted to estimate in situ PP: 9 in spring, 11 in summer, and 15 in autumn. Water was collected at each depth to fill three $250-\mathrm{mL}$ polycarbonate bottles, and these samples were inoculated with $100 \mu \mathrm{L}$ $(5 \mu \mathrm{Ci})$ of $\mathrm{NaH}^{14} \mathrm{CO}_{3}$ according to the method described by Steemann-Nielsen (1952). Two clear bottles and one dark bottle were placed in transparent acrylic tubes and incubated for $2 \mathrm{~h}$ at the original sampling depths, at about midday local time. Primary production $\left(\mathrm{mg} \mathrm{C} \cdot \mathrm{m}^{-3} \cdot \mathrm{h}^{-1}\right)$ was calculated according to Parsons et al. (1984) by subtracting the amount of assimilated carbon in the dark bottle.

During the 4 cruises, 54 experiments were conducted to estimate P-E curves. Water for the experiments was collected at depths corresponding to $50 \% E_{P A R}$, and it was used to fill 27 plain transparent polystyrene bottles for phytoplankton cultures with $250 \mathrm{~mL}$ capacity (Nunclon). Bottles were each coeficiente de absorción de luz por el fitoplancton $\left(a_{\phi}[\lambda]\right)$ fue calculado como la diferencia entre $a_{p}(\lambda)$ y $a_{d}(\lambda)$.

Las muestras de agua fueron también utilizadas para identificar y cuantificar el fitoplancton mediante la fijación con $2 \mathrm{~mL}$ de solución de Lugol neutralizado con ácido acético. Se colocó una alícuota de $50 \mathrm{~mL}$ en cámaras de sedimentación por $24 \mathrm{~h}$, y posteriormente las cámaras fueron analizadas en un microscopio invertido de acuerdo con la técnica de Utermöhl (1958).

En total se realizaron 35 experimentos para estimar la PP in situ: 9 en primavera, 11 en verano y 15 en otoño. En cada profundidad se recolectó agua para llenar 3 botellas de policarbonato de $250 \mathrm{~mL}$, y estas muestras fueron inoculadas con $100 \mu \mathrm{L}(5 \mu \mathrm{Ci})$ de $\mathrm{NaH}^{14} \mathrm{CO}_{3}$ de acuerdo con el método descrito por Steemann-Nielsen (1952). Dos botellas claras y una oscura fueron colocadas en tubos de acrílico transparente e incubadas por $2 \mathrm{~h}$ a las profundidades originales de muestreo cerca del mediodía local. La PP $\left(\mathrm{mg} \mathrm{C} \cdot \mathrm{m}^{-3} \cdot \mathrm{h}^{-1}\right)$ fue calculada de acuerdo con Parsons et al. (1984) restando la cantidad de carbono asimilado en la botella oscura.

Durante los 4 cruceros, se realizaron 54 experimentos para estimar las curvas P-E. El agua para los experimentos fue recolectada de la profundidad correspondiente al $50 \% E_{P A R}$, y fue utilizada para llenar 27 botellas planas transparentes de poliestireno de $250 \mathrm{~mL}$ para cultivo de fitoplancton (Nunclon). A cada botella se le agregaron $5 \mu \mathrm{Ci}$ de $\mathrm{NaH}^{14} \mathrm{CO}_{3}$ (Steemann-Nielsen 1952), y todas las botellas fueron incubadas por $2 \mathrm{~h}$ a un gradiente de luz que fue proporcionado por una lámpara de tungsteno-halógeno de $500 \mathrm{~W}$ de intensidad en un incubador tipo Morel (Babin et al. 1994). La intensidad de la luz en cada posición de la muestra fue determinada con un irradiómetro QSL-100 (Biospherical Instruments). El espectro de emisión de la lámpara no es espectralmente neutro, ya que es directamente dependiente de la longitud de onda, con una emisión mínima en el azul y máxima en el rojo (Bouman et al. 2000). Las tasas de fijación de carbono $\left(P, \mathrm{mg} \mathrm{C} \cdot \mathrm{m}^{-3} \cdot \mathrm{h}^{-1}\right)$ se calcularon a partir de los conteos de radiactividad substrayendo los valores de tiempo cero.

Los parámetros fotosintéticos $\alpha^{*}\left(\mathrm{mg} \mathrm{C} \cdot[\mathrm{mg} \mathrm{Chla}]^{-1} \cdot \mathrm{h}^{-1 /}\right.$ $\mu \mathrm{mol}$ fotones $\left.\cdot \mathrm{m}^{-2} \cdot \mathrm{s}^{-1}\right)$ y $P_{m}^{*}\left[\mathrm{mg} \mathrm{C} \cdot(\mathrm{mg} \mathrm{Chla})^{-1} \cdot \mathrm{h}^{-1}\right]$ se estimaron usando la función hiperbólica descrita por Jassby y Platt (1976): $P^{*}=P_{m}^{*} \operatorname{Tanh}\left[\left(\alpha^{*} E_{s}\right) / P_{m}^{*}\right]$, a partir de las tasas de asimilación de carbono normalizadas por la Chla de la muestra $\left(P^{*}, \mathrm{mg} \mathrm{C} \cdot[\mathrm{mg} \mathrm{Chla}]^{-1} \cdot \mathrm{h}^{-1}\right)$ y la irradiancia de la lámpara $\left(E_{s}\right)$ medida en el interior de cada botella. El parámetro de saturación de luz $\left(E_{k}, \mu \mathrm{mol}\right.$ fotones $\left.\cdot \mathrm{m}^{-2} \cdot \mathrm{s}^{-1}\right)$ está definido como la relación $P_{m}^{*} / \alpha^{*}$.

Se utilizaron los valores de $\alpha^{*}$ derivados de las curvas P-E y los valores del promedio del coeficiente específico de absorción de luz por el fitoplancton $\left(\bar{a}_{\phi L}^{*}\right)$ de las muestras del $50 \% E_{P A R}$, corregido por el espectro de la lámpara, para calcular $\phi_{\max }$ (mol C/mol fotones) a partir de la siguiente ecuación: $\phi_{\max }=0.023 \alpha^{*} / \bar{a}_{\phi L}^{*}$ (Schofield et al. 1991, Sosik 
spiked with $5 \mu \mathrm{Ci}$ of $\mathrm{NaH}^{14} \mathrm{CO}_{3}$ (Steemann-Nielsen 1952) and placed in a Morel type incubator for $2 \mathrm{~h}$ under a light gradient supplied by a $500-\mathrm{W}$ tungsten-halogen lamp (Babin et al. 1994). Light intensity at each position of the sample was determined with a QSL-100 irradiometer (Biospherical Instruments). The emission spectrum of the lamp is not spectrally neutral, as it is directly dependent on wave length, with a minimum emission in the blue and maximum in the red (Bouman et al. 2000). Carbon fixation rates $\left(P, \mathrm{mg} \mathrm{C} \cdot \mathrm{m}^{-3} \cdot \mathrm{h}^{-1}\right)$ were calculated from radioactive counts by subtracting the zero-time values .

The $\alpha^{*}$ (mg C $\cdot[\mathrm{mg} \mathrm{Chla}]^{-1} \cdot \mathrm{h}^{-1} / \mu \mathrm{mol}$ photons $\left.\cdot \mathrm{m}^{-2} \cdot \mathrm{s}^{-1}\right)$ and $P_{m}^{*}\left(\mathrm{mg} \mathrm{C} \cdot[\mathrm{mg} \mathrm{Chla}]^{-1} \cdot \mathrm{h}^{-1}\right)$ parameters were estimated using the hyperbolic function described by Jassby and Platt (1976): $P^{*}=P_{m}^{*} \operatorname{Tanh}\left[\left(\alpha^{*} E_{s}\right) / P_{m}^{*}\right]$, where $P^{*}$ is the carbon assimilation rate normalized to Chla content in the sample $\left(P^{*}, \mathrm{mg} \mathrm{C} \cdot[\mathrm{mg} \mathrm{Chla}]^{-1} \cdot \mathrm{h}^{-1}\right)$ and $E_{s}$ is the irradiance of the lamp measured from inside each bottle. The light saturation parameter $\left(E_{k}, \mu \mathrm{mol}\right.$ photons $\left.\cdot \mathrm{m}^{-2} \cdot \mathrm{s}^{-1}\right)$ is defined as the $P_{m}^{*} / \alpha^{*}$ relationship.

The $\alpha^{*}$ values derived from the $\mathrm{P}-\mathrm{E}$ curves and the average light-specific absorption coefficient of phytoplankton $\left(a_{\phi L}^{*}\right)$ from the $50 \% E_{P A R}$ samples, corrected for the lamp's spectrum, were used to calculate $\phi_{\max }$ (mol C/mol photons) from the following equation: $\phi_{\max }=0.023 \alpha^{*} / a_{\phi L}^{*}$ (Schofield et al. 1991, Sosik 1996). The phytoplankton-specific spectral absorption coefficient $\left(a_{\phi}^{*}(\lambda)\right)$ values for each depth were corrected for the downward irradiance $\left(E_{d}[\lambda]\right)$ measured by the PRR-600, and they were normalized to Chla to obtain the average values of phytoplankton-specific absorption coefficients for each depth $\left(\bar{a}_{\phi(z)}^{*}\right)$. Moreover, $\alpha^{*}$ was estimated for each depth in the euphotic zone $\left(\alpha_{(z)}^{*}\right)$ using the following equation: $\alpha_{(z)}^{*}=43.2 \phi_{\max } a_{\phi(z)}^{*}($ Schofield et al. 1993).

To determine the $P_{m}^{*}$ vertical profiles $\left(P_{m(z)}^{*}\right)$, a constant value was used for the first half of the euphotic zone $\left(\mathrm{Z}_{\text {eu }}\right)$, from the surface to $10 \% E_{P A R}$, and a linear variation of $P_{m(z)}^{*}$ was considered for the second half of $Z_{\mathrm{eu}}$. Between $10 \%$ and $1 \% E_{P A R}$, these $P_{m}^{*}$ values represented $25 \%$ of their value in surface waters (Prézelin et al. 1987, Valdez-Holguín et al. 1998).

The study area was divided into northern $\left(31^{\circ} 1.2^{\prime}-\right.$ $28^{\circ} 57.2^{\prime} \mathrm{N}, 116^{\circ} 46.6^{\prime}-117^{\circ} 38.7^{\prime} \mathrm{W}$; lines $100-110$ ) and central $\left(29^{\circ} 22.9^{\prime}-24^{\circ} 55.1^{\prime} \mathrm{N}, 112^{\circ} 49.1^{\prime}-118^{\circ} 10.9^{\prime} \mathrm{W}\right.$; lines $\left.113-133\right)$ regions acording to the physical and biological properties (Lavaniegos et al. 2002). Each region was subdivided into 2 zones taking the coastal (36 to $145 \mathrm{~km}$ off the coast) and oceanic (180 to $290 \mathrm{~km}$ off the coast) stations into account (Fig. 1). Average $\alpha_{(z)}^{*}$ and $P_{m(z)}^{*}$ values were calculated for each zone and region in order to estimate regional average PP values using the semi-analytical model described by Platt and Sathyendranath (1988):
1996). Los valores de los espectros del coeficiente específico de absorción por el fitoplancton $a_{\phi}^{*}(\lambda)$ para cada profundidad se corrigieron por la irradiancia descendente $\left(E_{d}[\lambda]\right)$ medida con el PRR-600, y se normalizaron por la Chla para obtener valores promedio de los coeficientes específicos de absorción por el fitoplancton para cada profundidad $\left(\bar{a}_{\phi(z)}^{*}\right)$. Posteriormente, se estimó $\alpha^{*}$ para cada profundidad dentro de la zona eufótica $\left(\alpha_{(z)}^{*}\right)$ con la siguiente ecuación: $\alpha_{(z)}^{*}=43.2 \phi_{\max } \bar{a}_{\phi(z)}^{*}$ (Schofield et al. 1993)

Para conocer los perfiles verticales de $P_{m}^{*}\left(P_{m(z)}^{*}\right)$, se utilizó un valor constante para la primera mitad de la zona eufótica $\left(Z_{\text {eu }}\right)$, desde la superficie hasta el $10 \% E_{P A R}$, y se consideró una variación lineal de $P_{m(z)}^{*}$ para la segunda mitad de $Z_{\text {eu }}$. Entre el $10 \%$ y $1 \% E_{\text {PAR }}$, estos valores de $P_{m}^{*}$ representaron el $25 \%$ de su valor en las aguas superficiales (Prézelin et al. 1987, Valdez-Holguín et al. 1998).

El área de estudio fue dividida en región norte $\left(31^{\circ} 41.2^{\prime}-28^{\circ} 57.2^{\prime} \mathrm{N}, \quad 116^{\circ} 46.6^{\prime}-117^{\circ} 38.7^{\prime} \mathrm{W} ;\right.$ líneas 100 a 110$) \quad y$ en región central $\left(29^{\circ} 22.9^{\prime}-24^{\circ} 55.1^{\prime} \mathrm{N}\right.$, $112^{\circ} 49.1^{\prime}-118^{\circ} 10.9^{\prime} \mathrm{W}$; líneas 113 a 133 ) tomando en cuenta las características físicas y biológicas (Lavaniegos et al. 2002). Cada región fue subdividida en 2 zonas considerando las estaciones costeras (a partir de $36 \mathrm{~km}$ y hasta $145 \mathrm{~km}$ de la costa) y oceánicas (de 180 a $290 \mathrm{~km}$ de la costa) (Fig. 1). Los valores promedio de $\alpha_{(z)}^{*}$ y $P_{m(z)}^{*}$ fueron calculados para cada zona y región con el propósito de estimar valores promedio regionales de la PP a partir del modelo semianalítico de Platt y Sathyendranath (1988):

$$
P(z)=\frac{\operatorname{Chl}(z)\left[\alpha_{(z)}^{*} E_{z}(\mathrm{PAR})\right]}{\left\{1+\left[\left(\alpha_{(z)}^{*} E_{z}(\mathrm{PAR}) / P_{m(z)}^{*}\right]^{2}\right\}^{1 / 2}\right.}
$$

La distribución vertical de chla (Chl[z]) se obtuvo utilizando los valores superficiales estimados con datos de sensores remotos y los parámetros del perfil de Chla del modelo de Platt et al. (1988) calculados para la región frente a Baja California por Millán-Nuñez et al. (1997) para cada región y estación del año. Los perfiles verticales de la irradiancia $\left(E_{z}[\mathrm{PAR}]\right)$ medidos con el PRR-600 a través de la columna de agua fueron ajustados a un modelo de regresión. Los coeficientes de dicha regresión se utilizaron en conjunto con los valores de $E_{P A R}$ medidos por sensores remotos para estimar los perfiles verticales promedio de la irradiancia para cada región por estación.

\section{RESUltados}

\section{Biomasa del fitoplancton}

En general, las concentraciones de Chla cerca de la superficie $(10 \mathrm{~m})$ fueron mayores en las estaciones costeras 


$$
P(z)=\frac{\operatorname{Chl}(\mathrm{z})\left[\alpha_{(z)}^{*} E_{z}(\mathrm{PAR})\right]}{\left\{1+\left[\left(\alpha_{(z)}^{*} E_{z}(\mathrm{PAR}) / P_{m(z)}^{*}\right]^{2}\right\}^{1 / 2}\right.}
$$

The vertical distribution of chla $(\mathrm{Chl}[\mathrm{z}])$ was obtained using the surface values estimated with remote sensing data and the Chla profile parameters from the model by Platt et al. (1988), which were calculated for the area off Baja California by Millán-Nuñez et al. (1997) for each region and each season of the year. The vertical profiles for irradiance $\left(E_{z}[\mathrm{PAR}]\right)$ measured throughout the water column with the PRR-600 were fitted to a regression model. The regression coefficients, together with the $E_{P A R}$ values measured by remote sensors, were used to estimate average irradiance vertical profiles for each region per season.

\section{RESULTS}

\section{Phytoplankton Biomass}

In general, Chla concentrations near the surface $(10 \mathrm{~m})$ were higher at the coastal than at the oceanic stations (Fig. 2). In winter, Chla concentration in the coastal zone of line 110 (northern region) was $2.8 \mathrm{mg} \cdot \mathrm{m}^{-3}$, while in other coastal zones of the northern and central regions concentrations were $>1.0 \mathrm{mg} \cdot \mathrm{m}^{-3}$ (Fig. 2a). In spring Chla was $>2.0 \mathrm{mg} \cdot \mathrm{m}^{-3}$ at the coastal stations in both regions, with values up to $8.0 \mathrm{mg} \cdot \mathrm{m}^{-3}$ in lines 103-110 and 113-120 (Fig. 2b). Chlorophyll concentration in the central region was high in the summer, with values greater than $2.0 \mathrm{mg} \cdot \mathrm{m}^{-3}$ at the coastal stations of lines 113 (up to $3.5 \mathrm{mg} \cdot \mathrm{m}^{-3}$ ) and 127 (Fig. 2c). In autumn, the highest value was $7.5 \mathrm{mg} \cdot \mathrm{m}^{-3}$ and was recorded at the coastal stations of line 130 (Fig. 2d). The lowest Chla value in summer and autumn was recorded in the oceanic zone of both regions.

During winter, integrated Chla $\left(\mathrm{C}_{\text {int }}\right)$ showed a maximum of $141 \mathrm{mg} \cdot \mathrm{m}^{-2}$ at station 110.35 and high values at the coastal stations of lines 113 and 120. A value greater than $100 \mathrm{mg} \cdot \mathrm{m}^{-2}$ was also observed for the oceanic region (Fig. 3a). In spring, the highest $\mathrm{C}_{\text {int }}$ values were recorded at the coastal stations of lines 107 and 120, and the lowest in the oceanic zone (Fig. 3b). In summer high values were observed $\left(>100 \mathrm{mg} \cdot \mathrm{m}^{-2}\right)$ at the oceanic stations in the central and southern portions of the central region (Fig. 3c). On the other hand, in autumn, $C_{\text {int }}$ values were up to $419 \mathrm{mg} \cdot \mathrm{m}^{-2}$ at station 130.55, and lower in the rest of the area (Fig. $3 \mathrm{~d}$ ). The average $\mathrm{C}_{\text {int }}$ value for the whole study period was higher in the coastal zone of the northern and central regions (40 and $49 \mathrm{mg} \cdot \mathrm{m}^{-2}$, respectively), with the highest averages observed in spring and autumn. In the oceanic zone $\mathrm{C}_{\mathrm{int}}$ the average was 20 and $29 \mathrm{mg} \cdot \mathrm{m}^{-2}$ in both regions, respectively (Table 1). que en las estaciones oceánicas (Fig. 2). En el invierno, la concentración de Chla en la zona costera de la línea 110 (región norte) fue de $2.8 \mathrm{mg} \cdot \mathrm{m}^{-3}$, mientras que en otras zonas costeras de las regiones norte y central, las concentraciones fueron mayores que $1.0 \mathrm{mg} \cdot \mathrm{m}^{-3}$ (Fig. 2a). En la primavera, la concentración de Chla fue mayor que $2.0 \mathrm{mg} \cdot \mathrm{m}^{-3}$ en las estaciones costeras de ambas regiones, con valores de hasta $8.0 \mathrm{mg} \cdot \mathrm{m}^{-3}$ en las líneas $103-110$ y $113-120$ (Fig. 2b). La Chla en la región central fue alta en verano, con concentraciones mayores que $2.0 \mathrm{mg} \cdot \mathrm{m}^{-3}$ en las estaciones costeras de las líneas 113 (hasta $3.5 \mathrm{mg} \cdot \mathrm{m}^{-3}$ ) y 127 (Fig. 2c). Para el otoño, el valor más alto fue de $7.5 \mathrm{mg} \cdot \mathrm{m}^{-3}$ y se registró en las estaciones costeras de la línea 130 (Fig. 2d). En el verano y otoño, la concentración de Chla más baja fue registrada en la zona oceánica de ambas regiones.

Durante el invierno, la Chla integrada $\left(\mathrm{C}_{\mathrm{int}}\right)$ presentó un máximo de $141 \mathrm{mg} \cdot \mathrm{m}^{-2}$ en la estación $110.35 \mathrm{y}$ valores altos en las estaciones costeras de las líneas 113 y 120. En la región oceánica también se observó un valor mayor que $100 \mathrm{mg} \cdot \mathrm{m}^{-2}$ (Fig. 3a). En primavera se registraron los valores más altos de $\mathrm{C}_{\mathrm{int}}$ en las estaciones costeras de las líneas $107 \mathrm{y}$ 120, y los más bajos en la zona oceánica (Fig. 3b). En verano se observaron valores altos $\left(>100 \mathrm{mg} \cdot \mathrm{m}^{-2}\right)$ en las estaciones oceánicas del centro y sur de la región central (Fig. 3c). Por otro lado, durante el otoño, la $\mathrm{C}_{\text {int }}$ presentó un valor de hasta $419 \mathrm{mg} \cdot \mathrm{m}^{-2}$ en la estación $130.55 \mathrm{y}$ valores menores en el resto del área (Fig. 3d). El promedio de la $\mathrm{C}_{\text {int }}$ para todo el periodo de estudio fue mayor en la zona costera de las regiones norte y central ( $40 \mathrm{y} 49 \mathrm{mg} \cdot \mathrm{m}^{-2}$, respectivamente), con los promedios más altos observados en primavera y otoño. En la zona oceánica, la $C_{\text {int }}$ promedio fue de 20 y $29 \mathrm{mg} \cdot \mathrm{m}^{-2}$ en la región norte y la región central, respectivamente (Tabla 1).

\section{Parámetros fotosintéticos}

Los valores promedio de $\alpha^{*}$ variaron de 0.005 a $0.024 \mathrm{mg}$ $\mathrm{C} \cdot(\mathrm{mg} \mathrm{Chla})^{-1} \cdot \mathrm{h}^{-1} \cdot\left(\mu \mathrm{mol} \text { fotones } \cdot \mathrm{m}^{-2} \cdot \mathrm{s}^{-1}\right)^{-1}$ en verano y primavera, respectivamente. Los valores de primavera fueron 4.6 veces mayor que los de verano y 1.6 veces más altos que los de invierno y otoño. También se registraron promedios 1.7 veces mayores en las estaciones costeras que en las estaciones oceánicas, y los valores más altos se registraron en la zona costera de la región central (Tabla 1). La abundancia de células grandes como las diatomeas (Chaetoceros spp. y Nitzschia spp., $3.2 \times 10^{5} \mathrm{cel} \cdot \mathrm{L}^{-1}$ ) y los dinoflagelados (Scrippsiella trochoidea y Protoperidinium spp., $1.36 \times$ $10^{5} \mathrm{cel} \cdot \mathrm{L}^{-1}$ ) estuvieron asociadas con valores mayores de $\alpha^{*}$ en las zonas costeras de las regiones norte y central.

Contrario a la distribución espacial de $\alpha^{*}$, la $P_{m}^{*}$ fue más alta durante otoño y verano, con valores promedio de $5.7 \mathrm{y}$ $3.9 \mathrm{mg} \mathrm{C} \cdot(\mathrm{mg} \mathrm{Chla})^{-1} \cdot \mathrm{h}^{-1}$, respectivamente. La $P_{m}^{*}$ en otoño fue 2.4 y 1.9 veces mayor que los valores de invierno y primavera, respectivamente. Durante el otoño la comunidad 


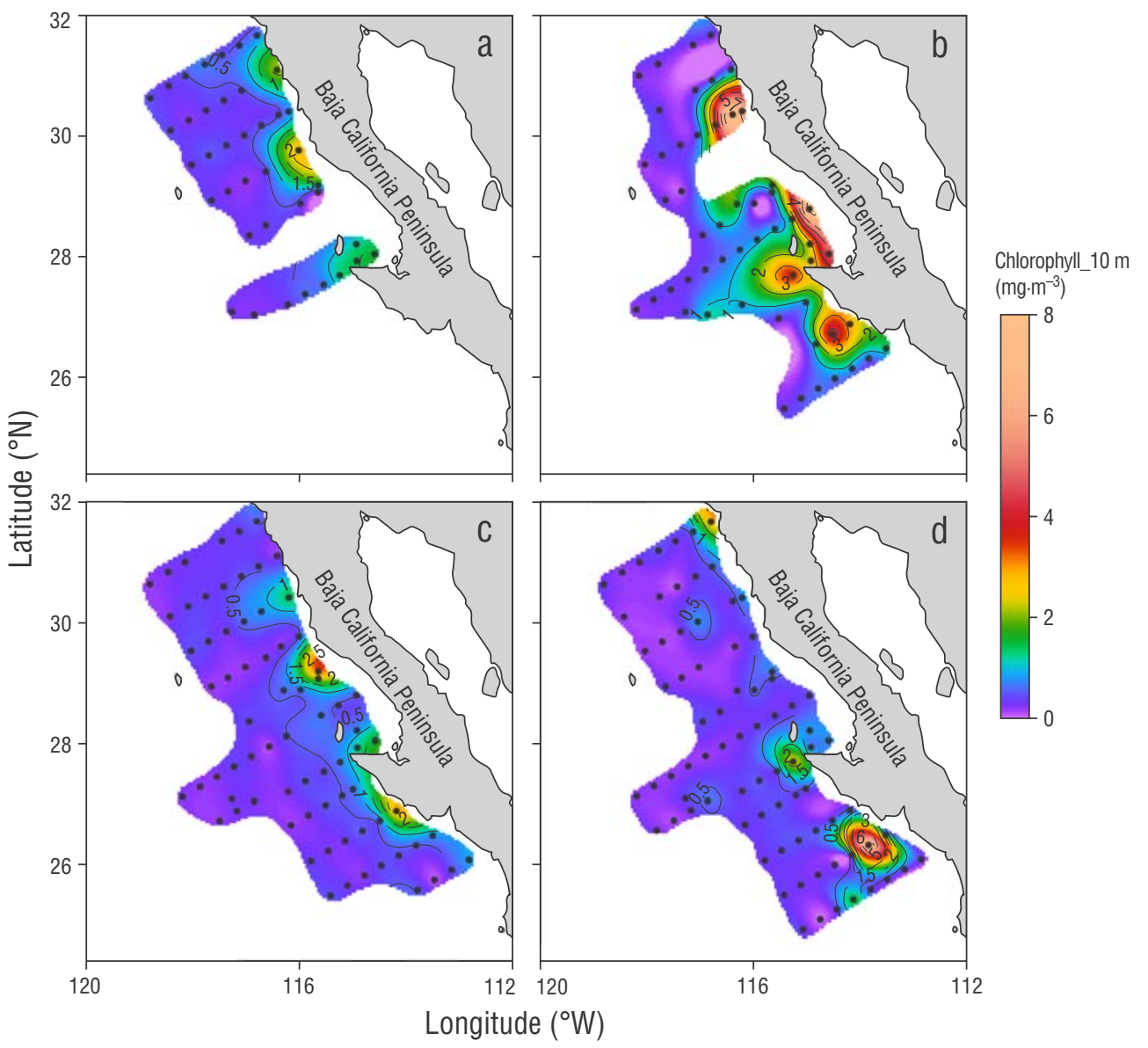

Figure 2. Spatial variability of chlorophyll concentration at $10 \mathrm{~m}$ depth measured at the sampling stations during each cruise in winter (a), spring (b), summer (c), and autumn (d).

Figura 2. Variabilidad espacial de la concentración de clorofila a $10 \mathrm{~m}$ de profundidad medida en las estaciones de muestreo durante cada crucero en invierno (a), primavera (b), verano $(\mathbf{c})$ y otoño $(\mathbf{d})$.

\section{Photosynthetic Parameters}

The average $\alpha^{*}$ values varied from 0.005 to $0.024 \mathrm{mg}$ $\mathrm{C} \cdot(\mathrm{mg} \mathrm{Chla})^{-1} \cdot \mathrm{h}^{-1} \cdot\left(\mu \mathrm{mol} \text { photons } \cdot \mathrm{m}^{-2} \cdot \mathrm{s}^{-1}\right)^{-1}$ in summer and spring, respectively. Values in spring were 4.6 times higher than in summer and 1.6 times higher than in winter and autumn. In addition, average values were 1.7 times higher at the coastal stations than at the oceanic stations, and the highest values were reported for the coastal zone of the central region. The abundance of large cells such as diatoms (Chaetoceros spp. and Nitzschia spp., $3.2 \times 10^{5} \mathrm{cel} \cdot \mathrm{L}^{-1}$ ) and dinoflagellates (Scrippsiella trochoidea and Protoperidinium spp., $\left.1.36 \times 10^{5} \mathrm{cel} \cdot \mathrm{L}^{-1}\right)$ were associated with higher $\alpha^{*}$ values in the coastal zones of the northern and central regions.

Contrary to the spatial distribution of $\alpha^{*}, P_{m}^{*}$ was higher during autumn and summer, with average values of 5.7 and $3.9 \mathrm{mg} \mathrm{C} \cdot(\mathrm{mg} \mathrm{Chla})^{-1} \cdot \mathrm{h}^{-1}$, respectively. In autumn, $P_{m}^{*}$ was 2.4 and 1.9 times higher than the values reported for winter and spring, respectively. The autumn phytoplanktonic community was dominated by dinoflagellates $\left(1.3 \times 10^{5} \mathrm{cel} \cdot \mathrm{L}^{-1}\right)$ fitoplanctónica estuvo dominada por dinoflagelados $(1.3 \times$ $\left.10^{5} \mathrm{cel} \cdot \mathrm{L}^{-1}\right)$ y flagelados $\left(1.8 \times 10^{6} \mathrm{cel} \cdot \mathrm{L}^{-1}\right)$, lo que estuvo asociado con valores de $P_{m}^{*}$ más altos en comparación con las otras estaciones. En promedio la $P_{m}^{*}$ estimada para la región central $\left(4.7 \mathrm{mg} \mathrm{C} \cdot(\mathrm{mg} \mathrm{Chla})^{-1} \cdot \mathrm{h}^{-1}\right)$ fue mayor que la $P_{m}^{*}$ estimada para la región norte $\left(2.9 \mathrm{mg} \mathrm{C} \cdot[\mathrm{mg} \mathrm{Chla}]^{-1} \cdot \mathrm{h}^{-1}\right)$. La $P_{m}^{*}$ en las estaciones costeras de ambas regiones fue 1.4 veces mayor que en las estaciones oceánicas (Tabla 1).

Los valores estimados de $E_{k}$ fueron más altos para el crucero de verano, con un promedio de $921 \mu \mathrm{mol}$ fotones $\cdot \mathrm{m}^{-2} \cdot \mathrm{s}^{-1}$. Este valor fue 7 veces mayor que el promedio estimado para primavera. Además, se observaron altos valores de $E_{k}$ en las estaciones costeras y oceánicas de ambas regiones en verano y otoño (Tabla 1). Los resultados para $E_{k}$ sugieren que las células del fitoplancton estuvieron fotoaclimatadas a bajas irradiancias durante los cruceros de invierno y primavera, mientras que en verano las células del fitoplancton se aclimataron a altas irradiancias.

Los promedios de $\phi_{\max }$ variaron entre 0.012 y $0.055 \mathrm{~mol}$ $\mathrm{C} / \mathrm{mol}$ fotones en verano y primavera, respectivamente. Este 


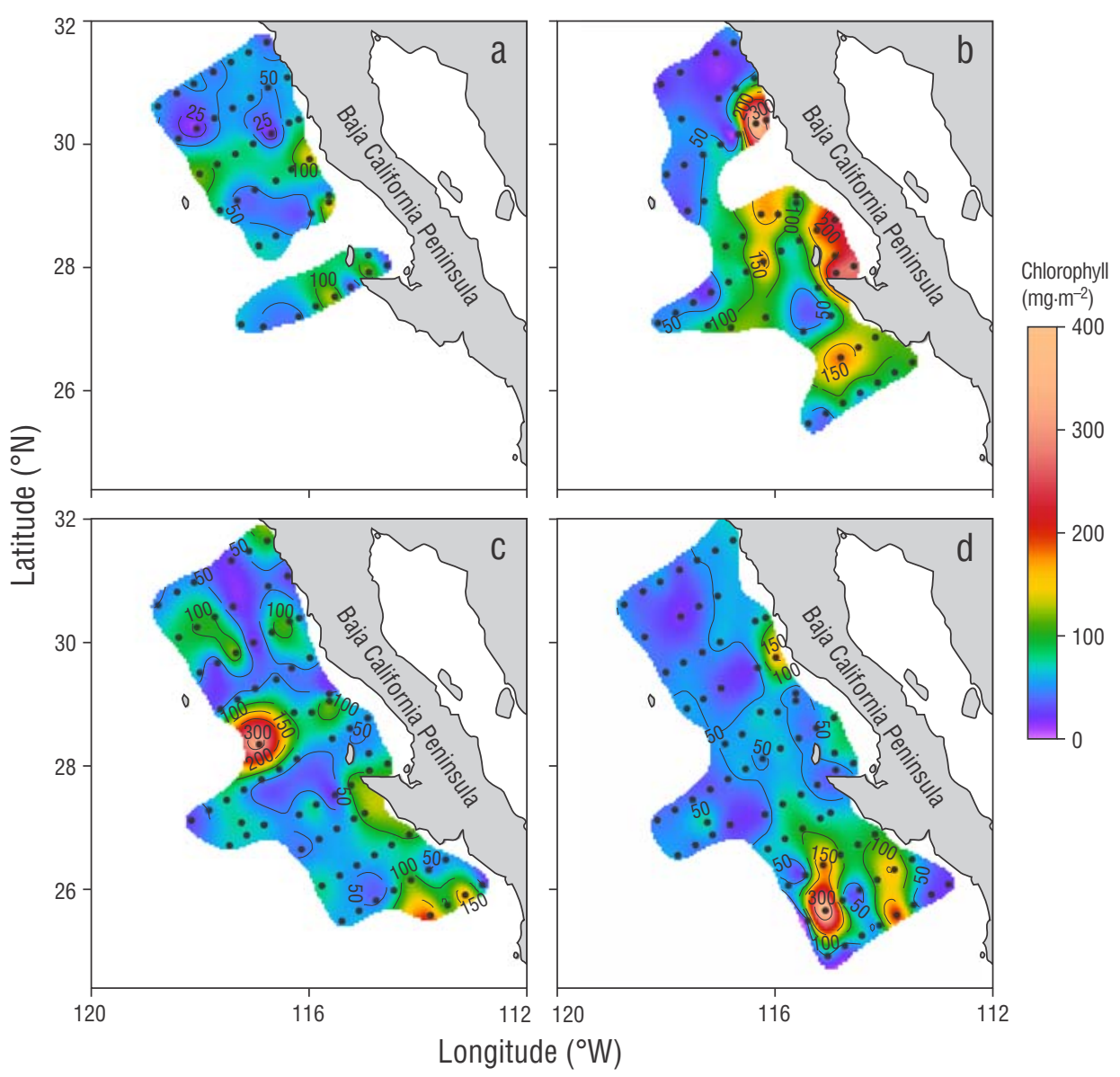

Figure 3. Spatial variability of chlorophyll integrated for the water column from cruise measurements taken in winter (a), spring (b), summer (c), and autumn (d).

Figura 3. Variabilidad espacial de la clorofila integrada para la columna de agua a partir de las mediciones de cada crucero tomadas en invierno (a), primavera (b), verano $(\mathbf{c})$ y otoño $(\mathbf{d})$.

and flagellates $\left(1.8 \times 10^{6} \mathrm{cel} \cdot \mathrm{L}^{-1}\right)$, and this was associated with higher $P_{m}^{*}$ values in comparison with the other seasons. On average the $P_{m}^{*}$ estimation for the central region (4.7 $\mathrm{mg} \mathrm{C} \cdot[\mathrm{mg} \mathrm{Chla}]^{-1} \cdot \mathrm{h}^{-1}$ ) was higher than that for the northern region $\left(2.9 \mathrm{mg} \mathrm{C} \cdot\left[\mathrm{mg} \mathrm{Chla}^{-1} \cdot \mathrm{h}^{-1}\right)\right.$. The $P_{m}^{*}$ estimate at the coastal stations of both regions was 1.4 times higher than at the oceanic stations (Table 1).

The highest $E_{k}$ estimates were recorded for the summer cruise, with an average of $921 \mu \mathrm{mol}$ photons $\cdot \mathrm{m}^{-2} \cdot \mathrm{s}^{-1}$. This value was 7 times higher than the average estimate for spring. Moreover, high $E_{k}$ values were recorded for the coastal and oceanic stations of both regions in summer and autumn (Table 1). The results for $E_{k}$ suggest that phytoplankton cells were photoaclimated to low irradiances during the winter and spring cruises, whereas in summer phytoplankton cells were acclimated to high irradiances.

The $\phi_{\max }$ averages ranged from 0.012 to $0.055 \mathrm{~mol} \mathrm{C} / \mathrm{mol}$ photons in summer and spring, respectively. The distribution of this parameter was similar to that of $\alpha^{*}$, with the highest values in the coastal zones of both the northern and central parámetro fotosintético mostró una distribución similar a la de $\alpha^{*}$, con los valores más altos en las zonas costeras de ambas regiones (norte y central) en el crucero de primavera (Tabla 1). Los valores de $\phi_{\max }$ estuvieron directamente relacionados con los altos valores de $\alpha^{*}$ estimados para este crucero y con el incremento en la abundancia de grandes células del fitoplancton como diatomeas y dinoflagelados.

\section{Producción primaria}

Durante el periodo de estudio, los valores promedio de la $\mathrm{PP}$ integrada $\left(\mathrm{PP}_{\mathrm{m}}\right)$ para la zona eufótica variaron entre $56 \mathrm{y}$ $114 \mathrm{mg} \mathrm{C} \cdot \mathrm{m}^{-2} \cdot \mathrm{h}^{-1}$ en invierno y primavera, respectivamente. Comparada con los valores estimados para el crucero de otoño, la $\mathrm{PP}_{\mathrm{m}}$ en la zona costera de la región norte fue 2.2 veces más alta en primavera. En contraste, los valores de $\mathrm{PP}_{\mathrm{m}}$ en la zona oceánica fueron 1.4 veces más altos durante el otoño. En la zona costera de la región central, el promedio de la $\mathrm{PP}_{\mathrm{m}}$ fue similar entre los diferentes cruceros. Sin embargo, la $\mathrm{PP}_{\mathrm{m}}$ estimada para la zona oceánica fue 1.8 veces más alta 


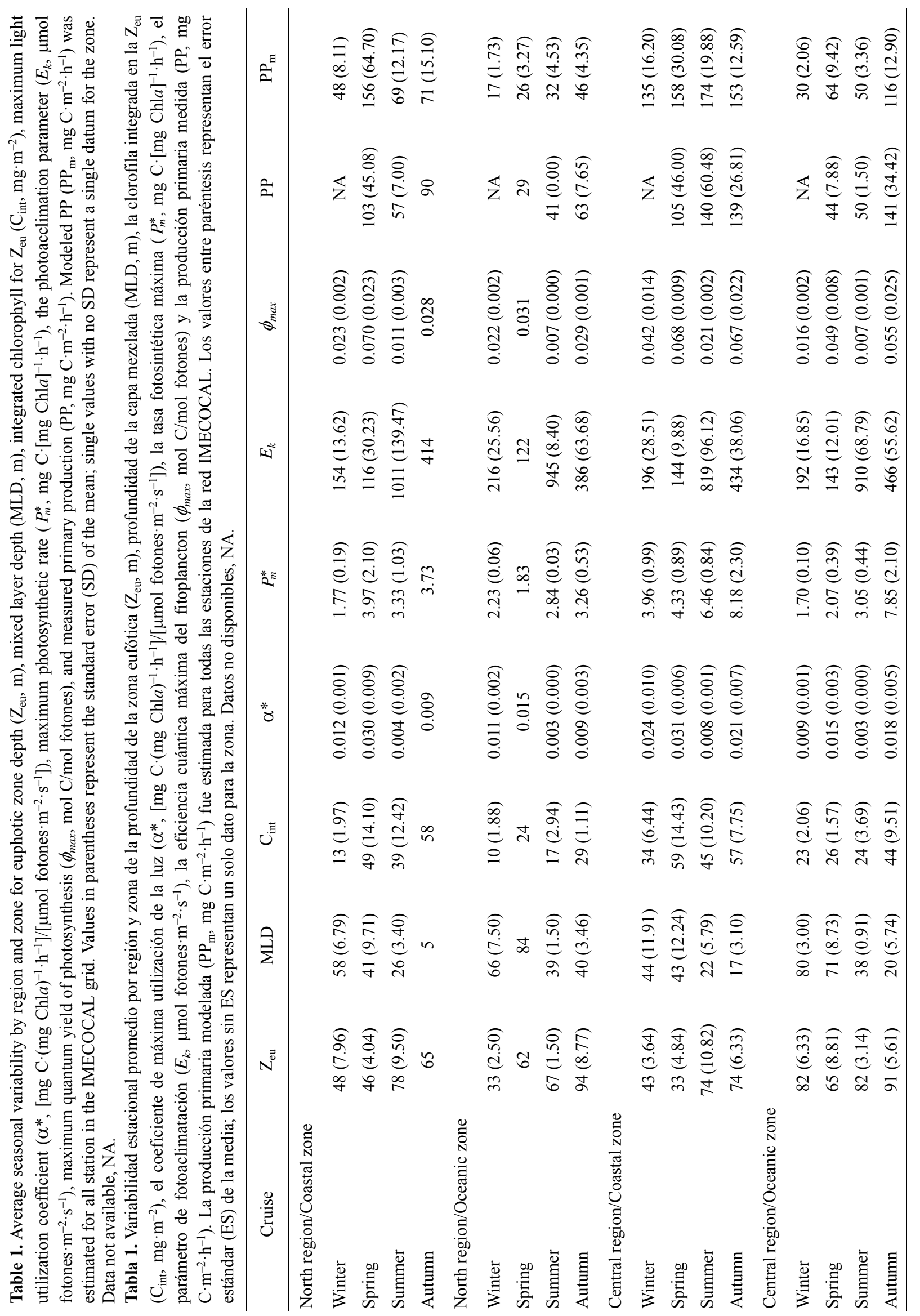


regions during the spring cruise (Table 1). The $\phi_{\max }$ values were directly correlated with the high $\alpha^{*}$ estimates for this cruise and with the increased abundance of large phytoplankton cells such as diatoms and dinoflagellates.

\section{Primary production}

During the study period the average values of integrated PP $\left(\mathrm{PP}_{\mathrm{m}}\right)$ for the euphotic zone varied between 56 and $114 \mathrm{mg} \mathrm{C} \cdot \mathrm{m}^{-2} \cdot \mathrm{h}^{-1}$ in winter and spring, respectively. Compared with the estimates for the autumn cruise, $\mathrm{PP}_{\mathrm{m}}$ in the coastal zone of the northern region was 2.2 times higher in spring. In contrast, the $\mathrm{PP}_{\mathrm{m}}$ values for the oceanic zone were 1.4 times higher during autumn. Average $\mathrm{PP}_{\mathrm{m}}$ for the coastal zone of the central region was similar among the different cruises. However, estimated $\mathrm{PP}_{\mathrm{m}}$ for the oceanic zone was 1.8 times higher in autumn compared to the rest of the year (Table 1). In general, observed $\mathrm{PP}_{\mathrm{m}}$ values were higher than $100 \mathrm{mg} \mathrm{C} \cdot \mathrm{m}^{-2} \cdot \mathrm{h}^{-1}$ at the coastal stations of the central region in winter (Fig. 4a). In spring, 2 highly productive zones $\left(>150 \mathrm{mg} \mathrm{C} \cdot \mathrm{m}^{-2} \cdot \mathrm{h}^{-1}\right.$ ) were detected at the coastal stations for both the northern and central regions (Fig. 4b). During the summer and autumn cruises, $\mathrm{PP}_{\mathrm{m}}$ estimates were higher than $150 \mathrm{mg} \mathrm{C} \cdot \mathrm{m}^{-2} \cdot \mathrm{h}^{-1}$ and showed a larger spatial extension in both regions, although $\mathrm{PP}_{\mathrm{m}}$ estimates were highest in the coastal zone of the central region and to the south of this region (Fig. 4 c, d).

The overall average for $\mathrm{PP}_{\mathrm{m}}$ was the same as the in situ PP average (94 $\mathrm{mg} \mathrm{C} \mathrm{m}^{-2} \mathrm{~h}^{-1}$ ). There was a high correlation $(r=0.85)$ between $\mathrm{PP}_{\mathrm{m}}$ and the PP estimate based on in situ ${ }^{14} \mathrm{C}$ experiments (Fig. 5a). When the photosynthetic parameters, PAR, and in situ Chla corresponding to the $50 \% E_{P A R}$ depth were introduced to the semi-analytical model proposed by Platt and Sathyendranath (1988), the linear regression model showed high correlation $(r=0.95)$ between $\mathrm{PP}_{\mathrm{m}}$ and in situ data for that depth (Fig. 5b). The $\mathrm{PP}_{\mathrm{m}}$ values estimated with the model for coastal waters of the northern and central regions was around 1.2 to 1.5 times higher than in situ $\mathrm{PP}$ estimates for spring and summer, whereas similar $\mathrm{PP}_{\mathrm{m}}$ and in situ PP estimates were recorded for autumn (Table 1). Furthermore, $\mathrm{PP}_{\mathrm{m}}$ was 1.2 times higher than in situ $\mathrm{PP}$ during spring but it was 0.9 and 0.8 times lower than in situ PP in oceanic waters of the central region during summer and autumn.

\section{DISCUSSION}

The $\mathrm{C}_{\text {int }}$ estimates for the coastal zone were higher during spring and autumn than during winter and summer but lower than the estimates for the 2000-2002 period reported by Gaxiola-Castro et al. (2010). Even though oceanographic conditions in 1999 were characteristic of a La Niña event, the effects on the ecosystem were apparently less intense then en otoño con relación al resto del año (Tabla 1). En general, observamos valores de $\mathrm{PP}_{\mathrm{m}}$ superiores a $100 \mathrm{mg} \mathrm{C} \cdot \mathrm{m}^{-2} \cdot \mathrm{h}^{-1}$ para las estaciones costeras de la región central en invierno (Fig. 4a). En primavera, se presentaron 2 zonas altamente productivas $\left(>150 \mathrm{mg} \mathrm{C} \cdot \mathrm{m}^{-2} \cdot \mathrm{h}^{-1}\right)$ en las estaciones costeras de la región norte y la región central (Fig. 4b). En los cruceros de verano y otoño se estimaron valores de $\mathrm{PP}_{\mathrm{m}}$ superiores a $150 \mathrm{mg} \mathrm{C} \cdot \mathrm{m}^{-2} \cdot \mathrm{h}^{-1}$, los cuales mostraron una mayor extensión espacial en las 2 regiones, aunque las $\mathrm{PP}_{\mathrm{m}}$ más altas fueron observadas en la zona costera de la región central y al sur de esta región (Fig. 4c, d).

El promedio general de la $\mathrm{PP}_{\mathrm{m}}$ fue igual al promedio de la PP in situ $\left(94 \mathrm{mg} \mathrm{C} \cdot \mathrm{m}^{-2} \cdot \mathrm{h}^{-1}\right)$. La $\mathrm{PP}_{\mathrm{m}}$ presentó alta correlación $(r=0.85)$ con la PP estimada a partir de experimentos in situ con ${ }^{14} \mathrm{C}$ (Fig. 5a). Cuando se introdujeron los parámetros fotosintéticos, la PAR y la Chla in situ correspondiente a la profundidad del $50 \%$ de $E_{P A R}$ al modelo semianalítico propuesto por Platt y Sathyendranath (1988), el modelo de regresión lineal produjo una alta correlación $(r=0.95)$ entre la $\mathrm{PP}_{\mathrm{m}}$ y los datos in situ de esa profundidad (Fig. 5b). La PP ${ }_{\mathrm{m}}$ calculada con el modelo para aguas costeras de la región norte y región central fue alrededor de 1.2 a 1.5 veces mayor que la PP estimada in situ en primavera y verano, mientras que en otoño, tanto la $\mathrm{PP}_{\mathrm{m}}$ como la $\mathrm{PP}$ medida in situ fueron similares (Tabla 1). Adicionalmente, la $\mathrm{PP}_{\mathrm{m}}$ fue 1.2 veces mayor que la PP in situ durante la primavera, pero fue $0.9 \mathrm{y}$ 0.8 veces menor que la PP in situ en aguas oceánicas de la región central durante el verano y otoño.

\section{Discusión}

$\mathrm{La} \mathrm{C}_{\mathrm{int}}$ registrada para la zona costera fue más alta durante la primavera y el otoño que durante el invierno y verano, pero menor que los valores reportados para el periodo 2000-2002 por Gaxiola-Castro et al. (2010). Aun cuando las condiciones oceanográficas durante 1999 fueron características de un evento La Niña, sus efectos en el ecosistema aparentemente fueron menos intensos que durante el evento La Niña que se presentó en 2002. Acorde con Gaxiola-Castro et al. (2010), el área de estudió se dividió en 3 zonas según la concentración de Chla: oligotrófica $\left(\leq 0.25 \mathrm{mg} \cdot \mathrm{m}^{-3}\right)$, mesotrófica $(>0.25 \mathrm{y}$ $\left.\leq 1.0 \mathrm{mg} \cdot \mathrm{m}^{-3}\right)$ y eutrófica $\left(>1.0 \mathrm{mg} \cdot \mathrm{m}^{-3}\right)$. La distribución espacial de la Chla es el resultado de los procesos de surgencias costeras, que ocurren con mayor intensidad durante la primavera (Durazo et al. 2010); de predominancia del flujo de la corriente de California que se dirige hacia el sur; y de las condiciones anómalamente frías debidas al evento $\mathrm{La}$ Niña. Estos procesos incrementan el aporte de nutrientes hacia la zona eufótica cerca de la costa y ocasionan un mayor crecimiento del fitoplancton (Gaxiola-Castro et al. 2010).

La variabilidad de $\alpha^{*}$ pareció responder a los cambios espaciales y temporales de las poblaciones de fitoplancton, dominadas principalmente por diatomeas y dinoflagelados 


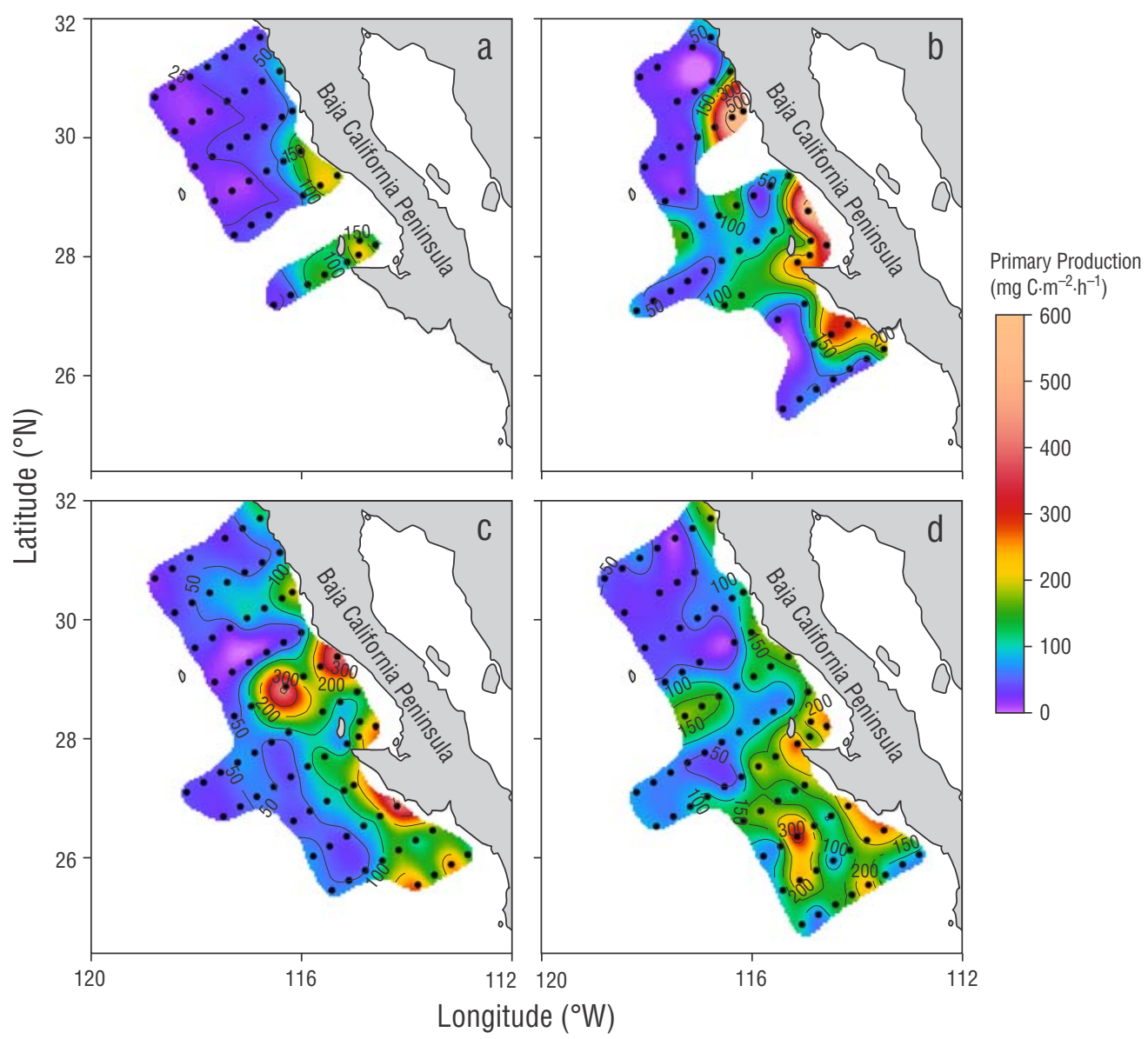

Figure 4. Primary production, estimated with the model proposed by Platt and Sathyendranath (1988), for winter (a), spring (b), summer (c), and autumn (d). Estimates are based on average vertical profiles of the maximum light utilization coefficient and maximum photosynthetic rate by zone and region, and on remote-sensing data.

Figura 4. Producción primaria estimada con el modelo de Platt y Sathyendranath (1988) para invierno (a), primavera (b), verano (c) y otoño (d). La estimaciones se hicieron a partir de los perfiles verticales promedio del coeficiente de máxima utilización de la luz y la tasa fotosintética máxima por zona y región, y de datos medidos por sensores remotos.

than during the La Niña event in 2002. In accordance with Gaxiola-Castro et al. (2010), the study area was divided into 3 zones depending on Chla concentrations: oligotrophic $\left(\leq 0.25 \mathrm{mg} \cdot \mathrm{m}^{-3}\right)$, mesotrophic $\left(>0.25\right.$ and $\left.\leq 1.0 \mathrm{mg} \cdot \mathrm{m}^{-3}\right)$, and eutrophic $\left(>1.0 \mathrm{mg} \cdot \mathrm{m}^{-3}\right)$. The spatial distribution of Chla depends on coastal upwelling processes, which occur with greater intensity during spring (Durazo et al. 2010); the prevailing southward flow of the California Current; and the anomalously cold conditions due to the La Niña event. These processes increase nutrient supply to the euphotic zone near the coast and enhance phytoplankton growth (Gaxiola-Castro et al. 2010).

The variability in $\alpha^{*}$ was apparently a response to the spatial and temporal changes in phytoplankton populations, which are primarily dominated by diatoms and dinoflagellates during spring. Furthermore, the changes seem to be related to phytoplankton photoacclimation and variations in $a_{\phi}(\lambda)$. In spring, phytoplankton was photoacclimated to low irradiances, with high $a_{\phi}(\lambda)$ values, which resulted in higher durante la primavera. Además, los cambios parecen estar relacionados con la fotoaclimatación del fitoplancton y las variaciones en el $a_{\phi}(\lambda)$. En primavera, el fitoplancton estuvo fotoaclimatado a bajas irradiancias, con altos valores de $a_{\phi}(\lambda)$, lo que originó que $\alpha^{*}$ fuera mayor en la zona costera de las regiones norte y central (Tabla 1). Estas diferencias en magnitud debido al tamaño del fitoplancton han sido reportadas previamente para la misma área de estudio por GonzalezMorales et al. (1993).

En general, los valores promedio de $\alpha^{*}$ fueron ligeramente superiores y los valores de $P_{m}^{*}$ fueron similares a los reportados por Aguirre-Hernández et al. (2004). Ambos parámetros fotosintéticos fueron inferiores a los calculados por Valdez-Holguín et al. (1998) para una estación frente a Ensenada, pero fueron similares a los estimados por Gonzalez-Morales et al. (1993), y por Schofield et al. (1993), quienes también observaron variabilidad estacional de estos parámetros fotosintéticos. Espinosa-Carreón et al. (2015) encontraron variabilidad de los parámetros fotosintéticos 
$\alpha^{*}$ values in the coastal zone of the northern and central regions (Table 1). These differences in magnitude due to phytoplankton size have been previously reported for the same study area by Gonzalez-Morales et al. (1993).

In general, average $\alpha^{*}$ values were slightly higher than and $P_{m}^{*}$ values were similar to those reported by AguirreHernández et al. (2004). Both photosynthetic parameters were lower than those estimated by Valdez-Holguin et al. (1998) for a station off Ensenada but were similar to those estimated by Gonzalez-Morales et al. (1993), and by Schofield et al. (1993), who also reported seasonal variability in these photosynthetic parameters. Espinosa-Carreón et al. (2015) reported variability in photosynthetic parameters during 2005, with high $\alpha^{*}$ values in winter and spring and high $P_{m}^{*}$ values in summer and autumn, similar to the behavior of data shown here. Geider (1993) reported minor dependence of $\alpha^{*}$ on irradiance growth, with higher interspecific variability in diatoms ( $\sim 5$-fold $)$. In cyanophytes, however, $\alpha^{*}$ decreases as irradiance increases due to the decreasing phycobiliproteins: Chla ratio during adaptation to high irradiances (Foy and Gibson 1982, Kana and Gilbert 1987).

The low $P_{m}^{*}$ estimates for winter and spring were apparently related to decreasing water temperature (13.0 to $17.0^{\circ} \mathrm{C}$ ), which decreases phytoplankton metabolism. In summer and autumn the increase in the water temperature, higher growth irradiance, and presence of smaller phytoplankton cells (flagellates) in the water column could have contributed to the increase in $P_{m}^{*}$ due to photophysiological acclimatization to high irradiances. Geider (1993) observed changes in $P_{m}^{*}$ between different sizes of phytoplankton cells and observed that diatoms showed low $P_{m}^{*}$ at the same growth irradiance. Furthermore, Valiela (1995) demonstrated variability in $P_{m}^{*}$, which increases with rising water temperature (see his figure 2-33).

The average $\phi_{\max }$ values estimated for the present study were similar to those reported by Schofield et al. (1993) for the area off southern California. These authors found that the observed high spatiotemporal variability was due to changes in phytoplankton photophysiology and community composition. Moreover, variability in $\phi_{\max }$ has been linked to changes in nutrient availability (Babin et al. 1996, Sathyendranath et al. 1996, Sosik 1996), spectral irradiance, photoperiods and light field (Dubinsky et al. 1984), temperature (Chamberlin and Marra 1992), increasing cellular concentration of photoprotective carotenoids at high irradiances (Bidigare et al. 1989), and the ratio of the absorption coefficient between blue and red light (Sathyendranath et al. 1996).

The high $\phi_{\max }$ estimates for the spring cruise were associated with the presence of larger phytoplankton cells, such as diatoms and dinoflagellates, and with high $a_{\phi}(\lambda)$ values. In contrast, low $\phi_{\max }$ estimates for summer and autumn were associated with the abundance of small phytoplankton cells. Dubinsky et al. (1986) observed a slight decrease in this durante 2005, con mayor $\alpha^{*}$ en invierno y primavera y alta $P_{m}^{*}$ en verano y otoño, similar al comportamiento de los datos aquí mostrados. Geider (1993) reportó una pequeña dependencia de $\alpha^{*}$ a la irradiancia de crecimiento, con una mayor variabilidad interespecífica en las diatomeas ( $\sim 5$ veces). Sin embargo, $\alpha^{*}$ disminuye en cianofitas con el aumento de la irradiancia, como resultado del decremento en la relación ficobiliproteínas:Chla durante la adaptación a altas irradiancias (Foy y Gibson 1982, Kana y Gilbert 1987).

Los bajos valores de $P_{m}^{*}$ estimados durante invierno y primavera aparentemente estuvieron relacionados con la disminución de la temperatura del agua $\left(13.0\right.$ a $\left.17.0^{\circ} \mathrm{C}\right)$, la cual favorece una disminución en el metabolismo del fitoplancton. En verano y otoño el incremento de la temperatura del agua, mayor irradiancia de crecimiento y la presencia de fitoplancton de menor tamaño (flagelados) en la columna de agua podrían ser la causa del aumento de $P_{m}^{*}$ debido a la aclimatación fotofisiológica a altas irradiancias. Geider (1993) observó cambios de $P_{m}^{*}$ entre células de fitoplancton de diferente tamaño, y observó que las diatomeas grandes tuvieron bajas $P_{m}^{*}$ a la misma irradiancia de crecimiento. Asimismo, Valiela (1995) mostró variabilidad de $P_{m}^{*}$, la cual se incrementa con el aumento de la temperatura del agua (ver su figura 2-33).

Los valores promedio de $\phi_{\max }$ estimados en este trabajo fueron similares a los reportados por Schofield et al. (1993) para la zona frente al sur de California. Estos autores encontraron que la alta variabilidad espaciotemporal observada fue debida a cambios en la fotofisiología del fitoplancton y a la composición de la comunidad. Además, la variabilidad de $\phi_{\max }$ ha sido relacionada con cambios en la disponibilidad de nutrientes (Babin et al. 1996, Sathyendranath et al. 1996, Sosik 1996), la irradiancia espectral, los fotoperiodos y el campo de luz (Dubinsky et al. 1984), la temperatura (Chamberlin y Marra 1992), el incremento en la concentración celular de carotenoides fotoprotectores a altas irradiancias (Bidigare et al. 1989), y la relación del coeficiente de absorción entre la luz azul y roja (Sathyendranath et al. 1996).

Los altos valores de $\phi_{\max }$ estimados para el crucero de primavera estuvieron relacionados con la presencia de células de fitoplancton de mayor tamaño, como diatomeas y dinoflagelados, y con altos valores del $a_{\phi}(\lambda)$. En contraste, los bajos valores de $\phi_{\max }$ en verano y otoño se asociaron con la abundancia de pequeñas células de fitoplancton. Dubinsky et al. (1986) observaron una ligera disminución de éste parámetro con alta irradiancia de crecimiento $(>500 \mu \mathrm{mol}$ fotones $\cdot \mathrm{m}^{-2} \cdot \mathrm{s}^{-1}$ ). Geider (1993) concluyó que $\phi_{\max }$ es principalmente independiente de la irradiancia en células que están creciendo con alta concentración de nutrientes.

Durante la primavera de 1999 las surgencias costeras fueron más intensas que lo normal frente a Baja California (Durazo y Baumgartner 2002). En esta época se estimaron altos valores de PP asociados con la alta concentración de 
parameter with high growth irradiance $(>500 \mu \mathrm{mol}$ photons $\cdot \mathrm{m}^{-2} \cdot \mathrm{s}^{-1}$ ). Geider (1993) concluded that $\phi_{\max }$ is mainly independent of the irradiance in cells growing under high nutrient concentrations.

In spring 1999 coastal upwelling was more intense than usual off Baja California (Durazo and Baumgartner 2002). High PP values associated with high Chla concentrations and higher diatom and dinoflagellate abundances were estimated for this season. In summer PP was high in both the northern and central regions, whereas in autumn values were higher than $150 \mathrm{mg} \mathrm{C} \cdot \mathrm{m}^{-2} \cdot \mathrm{h}^{-1}$ for both the coastal and the oceanic zones of the central region (Fig. 4, Table 1). Durazo et al. (2010) detected coastal upwelling in the northern region throughout the year, with higher intensity during spring, while coastal upwelling in the south occurred primarily during spring and summer. Sosa-Ávalos et al. (2005) reported strong northeasterly Santa Ana winds, which can fertilize coastal surface waters by coastal upwelling and vertical mixing (Castro et al. 2003, Trasviña et al. 2003). This eolic contribution can increase PP off Baja California (Fig. 4d, Table 1).

Average PP values were similar to those reported by Smith and Eppley (1982) for the coastal zone off southern California, which were associated with coastal upwelling events. Aguirre-Hernández et al. (2004) and EspinosaCarreón et al. (2015) reported lower integrated PP values for the region off Baja California in comparison to the values reported in this study, in which PP showed substantial seasonal variability.

The difference between $\mathrm{PP}_{\mathrm{m}}$ and in situ PP estimates for coastal waters in the northern and central regions during spring was due to the increased abundance in larger phytoplankton cells, which can contribute to variability in photosynthetic parameters. Additionally, the high $a_{\phi}(\lambda)$ values, observed mainly in the coastal zones, affected the calculations of $\alpha_{(z)}^{*}$ and $\phi_{\max }$ (Geider 1993). During summer and autumn, the $\mathrm{PP}_{\mathrm{m}}$ estimate for the coastal zones of both regions was similar to the in situ PP estimate. However, the observed in situ values were $20 \%$ higher than the $\mathrm{PP}_{\mathrm{m}}$ values for the oceanic zones during autumn.

The increase in Chla concentration in the coastal zone during spring was associated with coastal upwelling intensity. This zone was considered eutrophic due to the high Chla values, whereas the oceanic zone was considered oligotrophic. Photosynthetic parameters showed seasonal variability in the region off Baja California, with higher $\alpha^{*}$ and $\phi_{\max }$ estimates for coastal waters in spring and high $P_{m}^{*}$ in autumn. Moreover, the values of the photosynthetic parameters and bio-optical properties adequately represent the spatial variability in the oceanographic conditions that prevailed in the southern region of the California Current off Baja California. Thus, the proposed photosynthetic parameters and bio-optical properties for each region and season in this transition zone (a confluence zone of water masses with contrasting carachteristics) contribute to improve the development of
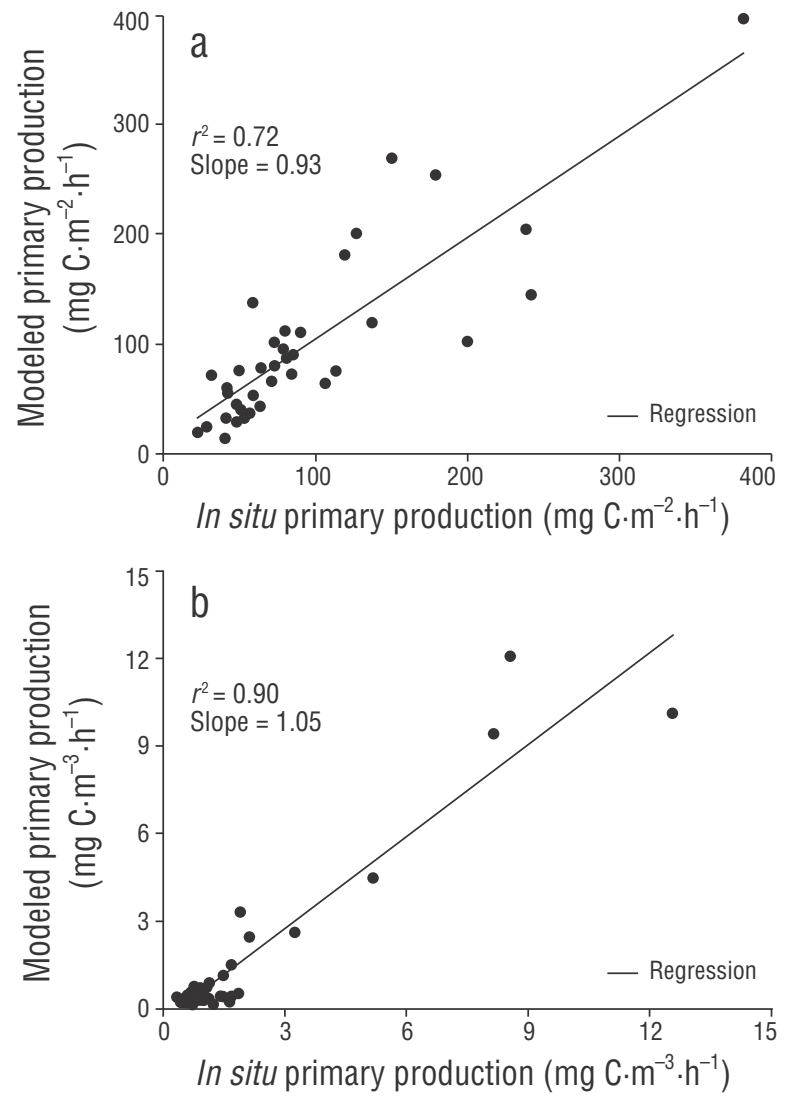

Figure 5. (a) Relationship between integrated primary production for the euphotic zone estimated with the model and that estimated with in situ measurements using the ${ }^{14} \mathrm{C}$ experiments. (b) Relationship between in situ and modeled primary production at the depth corresponding to $50 \%$ of surface irradiance $\left(E_{P A R}\right)$. The photosynthetic parameters of the photosynthesis-irradiance curves at $50 \% E_{P A R}$ were used in the model.

Figura 5. (a) Relación entre la producción primaria integrada para la zona eufótica estimada con el modelo y aquella estimada con las mediciones in situ mediante experimentos de ${ }^{14} \mathrm{C}$. (b) Relación entre la producción primaria in situ y la producción primara modelada en la profundidad correspondiente al $50 \%$ de irradiancia superficial $\left(E_{P A R}\right)$. Los parámetros fotosintéticos de las curvas de fotosintésis-irradiancia del $50 \% E_{P A R}$ se utilizaron en el modelo.

Chla y mayor abundancia de diatomeas y dinoflagelados. En verano se observó alta PP en la región norte y la región central, mientras que en otoño se presentaron valores mayores que $150 \mathrm{mg} \mathrm{C} \cdot \mathrm{m}^{-2} \cdot \mathrm{h}^{-1}$ en la zona costera y zona oceánica de la región central (Fig. 4, Tabla 1). Durazo et al. (2010) mostraron la presencia de surgencias costeras a lo largo del año en la región norte, con mayor intensidad en primavera, mientras que al sur, las surgencias costeras ocurrieron principalmente durante primavera y verano. Para otoño, SosaÁvalos et al. (2005) reportaron la presencia de fuertes vientos Santa Ana que provienen del NE, los cuales pueden generar fertilización de las aguas superficiales por surgencias costeras y mezcla vertical (Castro et al. 2003, Trasviña et al. 2003). Este aporte eólico puede ocasionar incrementos de la PP frente a Baja California (Fig. 4d, Tabla 1). 
regional algorithms. These algorithms, together with remote sensing data, will allow extrapolating PP estimations to regional or larger scales to better understand seasonal and interannual variability in PP associated with mesoscale and large-scale physical processes.

The results show that the average profiles for the photosynthetic parameters off Baja California change seasonally. This variability has important implications in PP estimations if constant values for these parameters are considered during an annual cycle. Therefore, the estimated PP values might not properly represent conditions in the ecosystem. A better option to estimate PP for the region off Baja California is to use remote sensing data and regional averages of the photosynthetic parameters for each season of the year. In general, the values for water-column integrated PP estimated with average $\alpha_{(z)}^{*}$ and $P_{m(z)}^{*}$ values and the model by Platt and Sathyendranath (1988) were similar to in situ PP estimates, with a correlation of 0.85 . These results suggest that the photosynthetic parameters proposed for the region can be applied to semi-analytical models to properly estimate PP. However, more information about these parameters under different oceanographic conditions is needed to solve for PP variability at interannual scales and to determine the phytoplankton carbon fixation rate in this transition zone.

\section{ACKNOWLEDGMENTS}

The National Council for Science and Technology (CONACYT, Mexico) and CICESE funded the cruises and laboratory work through projects G0041-T9607, DAJJ002/ 750/00, and G-35326T. The first author received a scholarship from the Mexican Secretariat of Public Education (SEPUCOL-98-05-01), the University of Colima, and CONACYT projects DAJJ002/750/00 and G35326T. We thank NASAGSFC-DAAC for providing SeaWiFS data. We are grateful for all the support received through the IMECOCAL program (Spanish acronym for Mexican Research of the California Current) and from all the participants during the 1999 cruises.

\section{English translation by Claudia Michel-Villalobos}

\section{REFERENCES}

Aguirre-Hernández E, Gaxiola-Castro G, Nájera-Martínez S, Baumgartner T, Kahru M, Mitchell BG. 2004. Phytoplankton absorption, photosynthetic parameters, and primary production off Baja California: summer and autumn 1998. Deep-Sea Res. II. 51(6-9): 799-816.

https://doi.org/10.1016/j.dsr2.2004.05.015

Babin M, Morel A, Claustre H, Bricaud A, Kolber Z, Falkowski PG. 1996. Nitrogen-and irradiance-dependent variations of the maximum quantum yield of carbon fixation in eutrophic, mesotrophic and oligotrophic marine systems. Deep-Sea Res. I. 43(8): 1241-1272.

https://doi.org/10.1016/0967-0637(96)00058-1
Los valores promedio de la PP fueron similares a los reportados por Smith y Eppley (1982) para la zona costera del sur de California, los cuales fueron relacionados con eventos de surgencias costeras. Aguirre-Hernández et al. (2004) y Espinosa-Carreón et al. (2015) reportaron valores de PP integrada para la región frente a Baja California que fueron inferiores a los registrados en el presente estudio, en el cual la PP mostró importante variabilidad estacional.

La diferencia entre la $\mathrm{PP}_{\mathrm{m}}$ y la $\mathrm{PP}$ in situ estimadas para aguas costeras de la región norte y la región central en primavera fue debida a la mayor abundancia de grandes células de fitoplancton, las cuales pueden contribuir a la variabilidad de los parámetros fotosintéticos. Adicionalmente, los altos valores del $a_{\phi}(\lambda)$, observados principalmente en las zonas costeras, afectaron los cálculos de $\alpha_{(z)}^{*}$ y $\phi_{\max }$ (Geider 1993). Durante el verano y otoño, la $\mathrm{PP}_{\mathrm{m}}$ calculada para las zonas costeras de ambas regiones fue similar a la PP estimada in situ. Sin embargo, observamos que los valores in situ fueron $20 \%$ mayores que los de la $\mathrm{PP}_{\mathrm{m}}$ para las zonas oceánicas durante el otoño.

El incremento de la concentración de Chla en la zona costera durante la primavera estuvo asociado con la intensidad de las surgencias costeras. Los altos valores de Chla observados en dicha zona permitieron definirla como una zona eutrófica, mientras que la zona oceánica fue considerada como oligotrófica. Los parámetros fotosintéticos mostraron variabilidad estacional en la región frente a Baja California, con valores más altos de $\alpha^{*}$ y $\phi_{\max }$ estimados para aguas costeras durante primavera y altas $P_{m}^{*}$ en otoño. Además, se observó que los valores de los parámetros fotosintéticos y las propiedades bio-ópticas representan adecuadamente la variabilidad espacial de las condiciones oceanográficas que prevalecieron en la región sur de la corriente de California frente a Baja California. Por tanto, los parámetros fotosintéticos y las propiedades bio-ópticas propuestos para cada región y estación del año en esta zona de transición, donde confluyen masas de agua con características contrastantes, contribuyen a mejorar el desarrollo de futuros algoritmos regionales. En conjunto con los datos derivados de sensores remotos, estos algoritmos permitirán extrapolar las estimaciones de PP a escalas regionales o mayores para entender mejor la variabilidad estacional e interanual de la PP asociada con los procesos físicos de mesoescala y de gran escala.

Los resultados muestran que los perfiles promedio de los parámetros fotosintéticos frente a Baja California cambian estacionalmente. Esta variabilidad estacional tiene implicaciones importantes en las estimaciones de la PP si se consideran valores constantes de estos parámetros durante un ciclo anual. Por consiguiente, los valores estimados de la PP podrían no representar adecuadamente lo que ocurre en el ecosistema. Una mejor opción para calcular la PP para la región frente a Baja California es usar datos de sensores remotos y promedios regionales de los parámetros fotosintéticos para cada estación del año. En general, los valores de la PP integrada en la columna de agua calculados 
Babin M, Morel A, Gagnon R. 1994. An incubator designed for extensive and sensitive measurements of phytoplankton photosynthetic parameters. Limnol. Oceanogr. 39(3): 694-702. http://dx.doi.org/10.4319/1o.1994.39.3.0694

Behrenfeld MJ, Falkowski PG. 1997. Photosynthetic rates derived from satellite-based chlorophyll concentration. Limnol. Oceanogr. 42(1): 1-20. http://dx.doi.org/10.4319/1o.1997.42.1.0001

Bidigare RR, Schofield O, Prézelin BB. 1989. Influence of zeaxanthin on quantum yield of photosynthesis of Synechococcus clone WH7803 (DC2). Mar. Ecol. Prog. Ser. 56: 177-188.

Bouman HA, Platt T, Kraay GW, Sathyendranath S, Irwin BD. 2000. Bio-optical properties of the subtropical North Atlantic. I. Vertical variability. Mar. Ecol. Prog. Ser. 200: 3-18. https://doi.org/10.3354/meps200003

Castro R, Parés-Sierra A, Marinone SG. 2003. Evolution and extension of the Santa Ana winds of February 2002 over the ocean, off California and the Baja California Peninsula = Evolución y extensión de los vientos Santa Ana de febrero de 2002 en el océano, frente a California y la península de Baja California. Cienc. Mar. 29(3): 275-281.

Chamberlin S, Marra J. 1992. Estimation of photosynthetic rate from measurements of natural fluorescence: analysis of the effects of light and temperature. Deep-Sea Res. 39(10): 1695-1706. https://doi.org/10.1016/0198-0149(92)90024-N

Dubinsky Z, Berman T, Schanz F. 1984. Field experiments for in situ measurements of photosynthetic efficiency and quantum yield. J. Plankton Res. 6(2): 339-349. https://doi.org/10.1093/plankt/6.2.339

Dubinsky Z, Falkowski PG, Wyman K. 1986. Light harvesting and utilization by phytoplankton. Plant Cell Physiol. 27(7): 1335-1349.

https://doi.org/10.1093/oxfordjournals.pcp.a077232

Durazo R. 2009. Climate and upper ocean variability off Baja California, Mexico: 1997-2008. Prog. Ocean. 83(1-4): 361-368. https://doi.org/10.1016/j.pocean.2009.07.043

Durazo R, Baumgartner TR. 2002. Evolution of oceanographic conditions off Baja California: 1997-1999. Prog. Oceanogr. 54(1-4): 7-31. https://doi.org/10.1016/S0079-6611(02)00041-1

Durazo R, Ramírez-Manguilar AM, Miranda LE, Soto-Mardones LA. 2010. Climatología de variables hidrográficas. In: GaxiolaCastro G Durazo R (eds.), Dinámica del Ecosistema Pelágico frente a Baja California 1997-2007: Diez años de Investigaciones Mexicanas de la Corriente de California. Secretaría de Medio Ambiente y Recursos Naturales, Mexico, pp. 25-57.

Espinosa-Carreón TL, Gaxiola-Castro G, Durazo R, De la CruzOrozco ME, Norzagaray-Campos M, Solana-Arellano E. 2015. Influence of anomalous subartic water intrusion on phytoplankton production off Baja California. Cont. Shelf Res. 92: 108-121. https://doi.org/10.1016/j.csr.2014.10.003

Foy RH, Gibson CE. 1982. Photosynthetic characteristics of planktonic blue-green algae: the response of twenty strains grown under high and low light. Br. Phycology Journal. 17(2): 169-182. http://dx.doi.org/10.1080/00071618200650171

Gaxiola-Castro G Cepeda-Morales J, Nájera-Martínez S, EspinosaCarreón TL, De la Cruz-Orozco ME, Sosa-Avalos R, AguirreHernández E, Cantú-Ontiveros JP. 2010. Biomasa y producción del fitoplancton. In: Gaxiola-Castro G Durazo R (eds.), con los valores promedio de $\alpha_{(z)}^{*}$ y $P_{m(z)}^{*}$, y el modelo de Platt y Sathyendranath (1988) fueron similares a las estimaciones de PP in situ, con una correlación de 0.85 . Estos resultados sugieren que los parámetros fotosintéticos propuestos para la región pueden ser aplicados a modelos semianalíticos para estimar adecuadamente la PP. Sin embargo, es necesario contar con más información de estos parámetros para diferentes condiciones oceanográficas que permita resolver la variabilidad de la PP a escalas interanuales y conocer la tasa de fijación de carbono por el fitoplancton en esta zona de transición.

\section{Agradecimientos}

El Consejo Nacional de Ciencia y Tecnología (CONACYT, México) y el CICESE financiaron los cruceros y el trabajo de laboratorio bajo los proyectos G0041-T9607, DAJJ002/750/00 y G-35326T. El primer autor recibió apoyo financiero de la Secretaría de Educación Pública (SEPUCOL-98-05-01), de la Universidad de Colima y de los proyectos CONACYT DAJJ002/750/00 y G35326T. Agradecemos al NASA-GSFC-DAAC el proporcionar los datos de SeaWiFS. Agradecemos también el apoyo recibido a través del programa oceanográfico Investigaciones Mexicanas de la Corriente de California (IMECOCAL) y por parte de todos los participantes durante los cruceros de 1999.

Dinámica del Ecosistema Pelágico frente a Baja California 1997-2007: Diez años de Investigaciones Mexicanas de la Corriente de California. Secretaría de Medio Ambiente y Recursos Naturales, Mexico, pp. 59-85.

Geider RJ. 1993. Quantitative phytoplankton physiology: implications for primary production and phytoplankton growth. ICES Mar. Sci. Symp. 197: 52-62.

Gonzalez-Morales AT, Gaxiola-Castro G, Lara-Lara JR. 1993. Daily photosynthetic parameters and biomass from size-fractionated phytoplankton off Baja California. Estuarine, Coastal and Shelf Science. 36(2): 147-158. https://doi.org/10.1006/ecss.1993.1010

Holm-Hansen O, Lorenzen CJ, Holm RW, Strickland JDH. 1965. Fluorometric determination of chlorophyll. J. Cons. Int. Explor. Mer. 30(1): 3-15.

Jassby AD, Platt T. 1976. Mathematical formulation of the relationship between photosynthesis and light for phytoplankton. Limnol. Oceanogr. 21(4): 540-547. https://doi.org/10.4319/1o.1976.21.4.0540

Kana TM, Gilbert PM. 1987. Effect of irradiances up to $2000 \mu \mathrm{E}$ $\mathrm{m}^{-2} \mathrm{~s}^{-1}$ on marine Synechococcus WH7803-I. Growth, pigmentation, and cell composition. Deep-Sea Res. Part A, 34(4): 479-495.

Kishino M, Takahashi M, Okami N, Ichimura S. 1985. Estimation of the spectral absorption coefficients of phytoplankton in the sea. Bull. Mar. Sci. 37(2): 634-642.

Longhurst A, Sathyendranath S, Platt T, Caverhill C. 1995. An estimate of global primary production in the ocean from satellite radiometer data. J. Plankton Res. 17(6): 1245-1271. https://doi.org/10.1093/plankt/17.6.1245 
Lavaniegos BE, Jiménez-Pérez JC, Gaxiola-Castro G. 2002. Plankton response to El Niño 1997-1998 and La Niña 1999 in the southern región of the California Current. Prog. Oceanogr. 54(1-4): 33-58. https://doi.org/10.1016/S0079-6611(02)00042-3

Millán-Nuñez R, Alvarez-Borrego S, Trees CC. 1997. Modeling the vertical distribution of chlorophyll in the California Current System. J. Geophys. Res. 102(C4): 8587-8595. https://doi.org/10.1029/97JC00079

Mitchell BG. 1990. Algorithms for determining the absorption coefficient of aquatic particulates using the quantitative filter technique. Ocean Optics X (1302): 137-148. https://doi.org/10.1117/12.21440

Mitchell BG, Kahru M, Wieland J, Stramska M. 2003. Determination of spectral absorption coefficients of particles, dissolved material and phytoplankton for discrete water samples. In: Mueller JL, Fargion GS, McClain CR (eds.), Ocean Optics Protocols for Satellite Ocean Color Sensor Validation, Revision 4, Volume IV: Inherent Optical Properties: Instruments, Characterizations, Field Measurements and Data Analysis Protocols. NASA Tech. Memo. 2003-211621, pp. 39-64.

Parsons TR, Maita Y, Lalli, CM. 1984. A manual of chemical and biological methods for seawater analysis. Pergamon Press, $173 \mathrm{pp}$.

Platt T, Caverhill C, Sathyendranath S. 1991. Basin-scale estimates of oceanic primary production by remote sensing: the North Atlantic. J. Geophys. Res. 96(C8): 15147-15159. https://doi.org/10.1029/91JC01118

Platt T, Sathyendranath S. 1988. Oceanic primary production: Estimation by remote sensing at local and regional scales. Science. 241(4873): 1613-1620.

Platt T, Sathyendranath S, Caverhill CM, Lewis MR. 1988. Ocean primary production and available light: further algorithms for remote sensing. Deep-Sea Res. Part A, 35(6): 855-879. https://doi.org/10.1016/0198-0149(88)90064-7

Prézelin BB, Bidigare RR, Matlick HA, Putt M, Verhoven B. 1987. Diurnal patterns of size-fractionated primary production across a coastal front. Mar. Biol. 96(4): 563-574.

Sathyendranath S, Longhurst A, Caverhill CM, Platt T. 1995. Regionally and seasonally differentiated primary production in the North Atlantic. Deep-Sea Res. 42(10): 1773-1802. https://doi.org/10.1016/0967-0637(95)00059-F

Sathyendranath S, Platt T. 1989. Remote sensing of ocean chlorophyll: consequence of nonuniform pigment profile. Applied Optics. 28(3): 490-495. https://doi.org/10.1364/AO.28.000490
Sathyendranath S, Platt T, Stuart V, Irwin BD, Veldhuis MJW, Kraay GW, Harrison WG. 1996. Some bio-optical characteristics of phytoplankton in the NW Indian Ocean. Mar. Ecol. Prog. Ser. 132: 299-311.

Schofield O, Prézelin BB, Bidigare RR, Smith RC. 1993. In situ photosynthetic quantum yield. Correspondence to hydrographic and optical variability within the Southern California Bight. Mar. Ecol. Prog. Ser. 93: 25-37.

Schofield O, Prézelin BB, Smith RC, Stegmann PM, Nelson NB, Lewis MR, Baker KS. 1991. Variability in spectral and nonspectral measurements of photosynthetic light utilization efficiencies. Mar. Ecol. Prog. Ser. 78: 253-271.

Smith PE, Eppley RW. 1982. Primary production and the anchovy populations in the Southern California Bight: Comparison of time series. Limnol. Oceanogr. 27(1): 1-17. https://doi.org/10.4319/lo.1982.27.1.0001

Sosa-Ávalos R, Gaxiola-Castro G, Durazo R, Mitchell BG. 2005. Effect of Santa Ana winds on bio-optical properties off Baja California $=$ Efecto de los vientos Santa Ana en las propiedades bio-ópticas frente a Baja California. Cienc. Mar. 31(2): 339-348.

Sosik HM. 1996. Bio-optical modeling of primary production: consequences of variability in quantum yield and specific absorption. Mar. Ecol. Prog. Ser. 143: 225-238.

Steemann Nielsen E. 1952. The use of radioactive carbon 14C for measuring organic production in the sea. ICES J. Mar. Sci. 18(2): 117-140. https://doi.org/10.1093/icesjms/18.2.117

Trasviña A, Ortiz-Figueroa M, Herrera H, Cosío MA, González E. 2003. Santa Ana winds and upwelling filaments off northern Baja California. Dyn. Atmos. Oceans. 37(2): 113-129. https://doi.org/10.1016/S0377-0265(03)00018-6

Utermöhl H. 1958. Zur Vervollkommung der quantitativen phytoplankton-methodik. Mitteilungen. Internat. Vereinigung fur Theoretische und Angewandte Limnol. 9: 1-38.

Valdez-Holguín JE, Alvarez-Borrego S, Mitchell BG. 1998. Photosynthetic parameters of phytoplankton in the California Current System. CalCOFI Rep. 39: 148-158.

Valiela I. 1995. Marine Ecological Processes. Springer-Verlag, New York, $686 \mathrm{pp}$. https://doi.org/10.1007/978-0-387-79070-1

Venrick EL, Hayward TL. 1984. Determining chlorophyll on the 1984 Calcofi surveys. CalCOFI Rep. 25: 74-79.

Yentsch CS, Menzel DW. 1963. A method for the determination of phytoplankton, chlorophyll and phaeophytin by fluorescence. Deep-Sea Res. 10(3): 221-231. https://doi.org/10.1016/0011-7471(63)90358-9

Received March 2017, Accepted May 2017. 